\title{
ORNL's 3rd Annual Southeast Sustainability Summit
}

\section{Summit Proceedings}

Presented by Oak Ridge National Laboratory and the Tennessee Energy Education Initiative

Holiday Inn World's Fair Park, Knoxville, TN

August 21-22, 2013
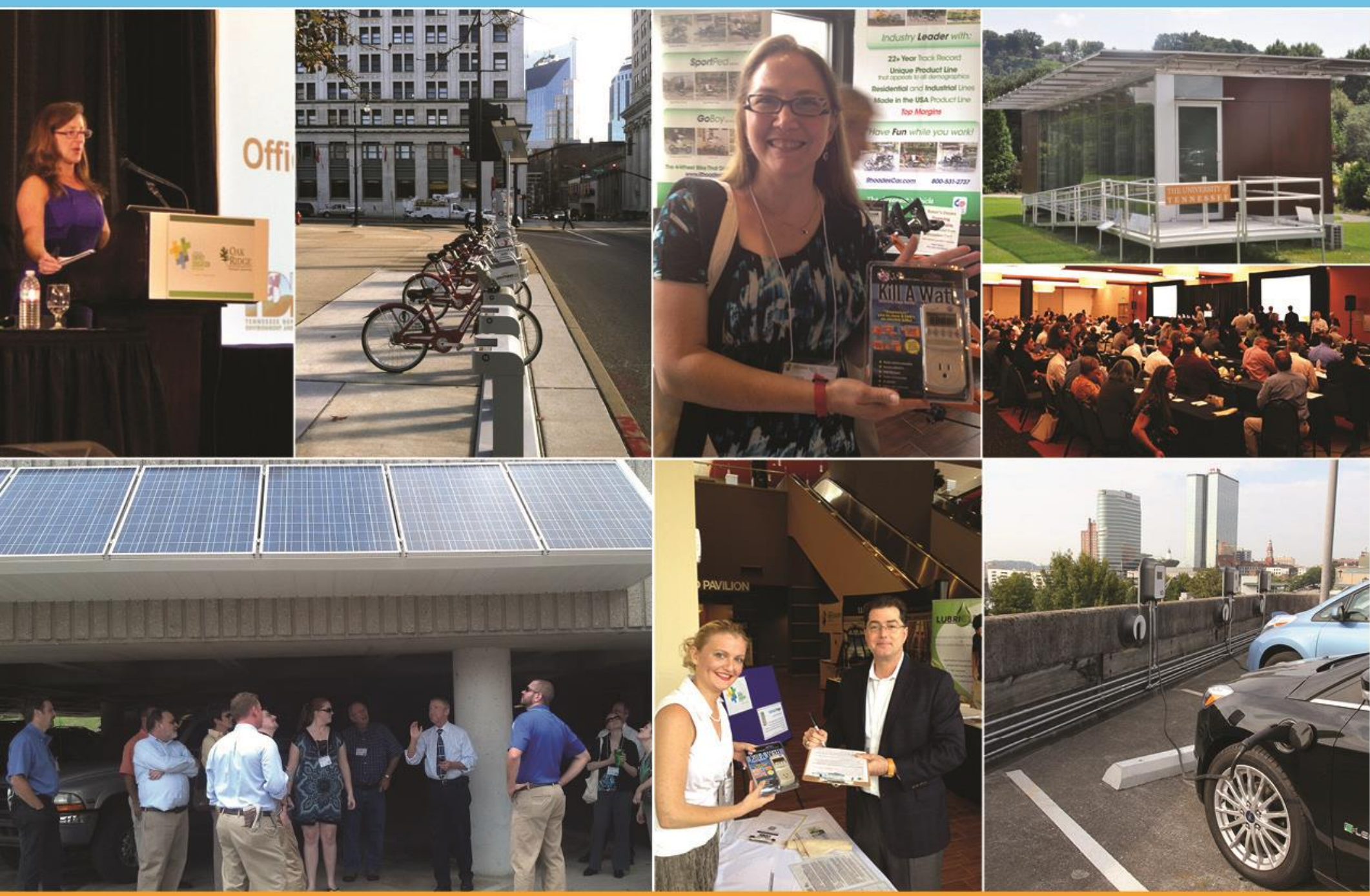

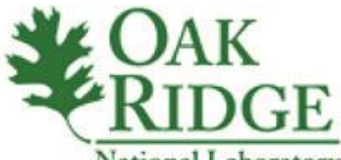

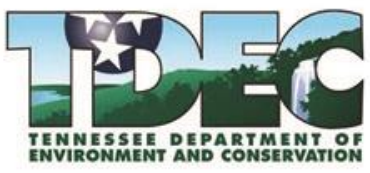

2. SENTECH, Inc.

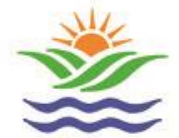

CITY OF KNOXVILLE

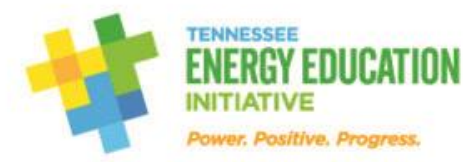

Xe Pathway 


\section{DOCUMENT AVAILABILITY}

Reports produced after January 1, 1996, are generally available free via the U.S. Department of Energy (DOE) Information Bridge.

Web site http://www.osti.gov/bridge

Reports produced before January 1, 1996, may be purchased by members of the public from the following source.

National Technical Information Service

5285 Port Royal Road

Springfield, VA 22161

Telephone 703-605-6000 (1-800-553-6847)

TDD 703-487-4639

Fax 703-605-6900

E-mailinfo@ntis.gov

Web site http://www.ntis.gov/support/ordernowabout.htm

Reports are available to DOE employees, DOE contractors, Energy Technology Data Exchange (ETDE) representatives, and International Nuclear Information System (INIS) representatives from the following source.

Office of Scientific and Technical Information

P.O. Box 62

Oak Ridge, TN 37831

Telephone 865-576-8401

Fax 865-576-5728

E-mail reports@osti.gov

Web site http://www.osti.gov/contact.html

This report was prepared as an account of work sponsored by an agency of the United States Government. Neither the United States Government nor any agency thereof, nor any of their employees, makes any warranty, express or implied, or assumes any legal liability or responsibility for the accuracy, completeness, or usefulness of any information, apparatus, product, or process disclosed, or represents that its use would not infringe privately owned rights. Reference herein to any specific commercial product, process, or service by trade name, trademark, manufacturer, or otherwise, does not necessarily constitute or imply its endorsement, recommendation, or favoring by the United States Government or any agency thereof. The views and opinions of authors expressed herein do not necessarily state or reflect those of the United States Government or any agency thereof. 
Energy and Transportation Science Division

ORNL's $3^{\text {rd }}$ Annual Southeast Sustainability Summit Summit Proceedings

December 2013

Melissa Lapsa, Oak Ridge National Laboratory

Molly Cripps, TDEC Office of Energy Programs Julia Blackburn, SENTECH, Inc.

Amy Bunton, Pathway Lending

Valerie Medovich, Pathway Lending

Teresa Nichols, Oak Ridge National Laboratory

Jake Tisinger, City of Knoxville

Prepared by

OAK RIDGE NATIONAL LABORATORY

Oak Ridge, Tennessee 37831-6283

managed by

UT-BATTELLE, LLC

for the

U.S. DEPARTMENT OF ENERGY

under contract DE-AC05-00OR22725 



\section{TABLE OF CONTENTS}

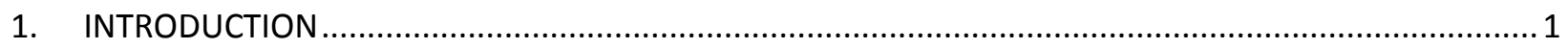

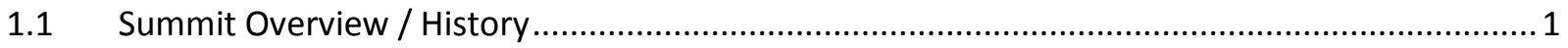

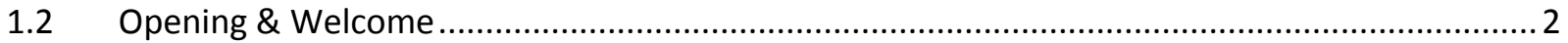

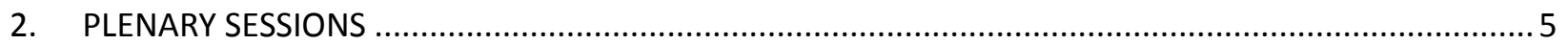

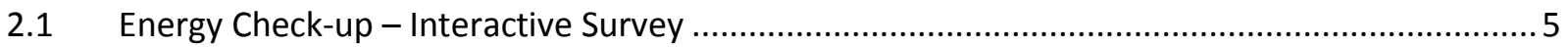

2.2 Road to Funding: ROI Analysis \& the Navigation of Funding Options ...................................... 5

2.3 Southeast Sustainability Group: Agents of Change .............................................................. 6

2.4 The Department of Energy's Role in Sustainability................................................................. 7

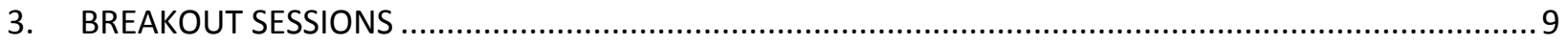

3.1 Qualified Energy Conservation Bonds (QECBs) Part 1 - Overview of Tennessee Program \& Best

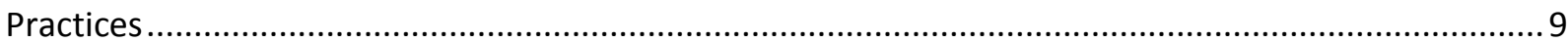

3.2 Qualified Energy Conservation Bonds Part 2 - Bond Financing \& Eligible QECB Projects............ 9

3.3 Driving Toward Sustainable Transportation .......................................................................... 10

3.4 Changing Behaviors in the Workplace - Employee Engagement ............................................ 11

3.5 Institutes for Sustainable Research, Development \& Deployment ........................................ 12

3.6 Energy Management Case Studies - A Look at Three Unique Industry Sectors....................... 13

3.7 Lighting Upgrades - The Gateway to Energy Efficiency........................................................ 14

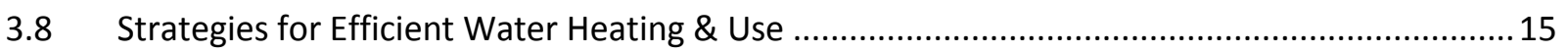

3.9 Ground Source Heat Pumps - Challenges \& Opportunities .................................................... 16

3.10 Bike Share - A Better Way to Travel .................................................................................. 17

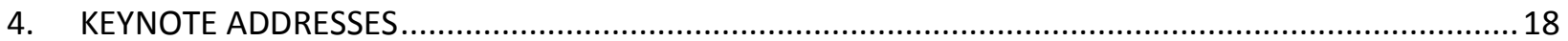

4.1 A Better Way - Restoring the Long-Term Economic, Social \& Environmental Health of Our

Cities

4.2 Behavior Change - From Individuals to Institutions ........................................................... 18

4.3 Doubling Energy Productivity in the Southeast - The Key to Becoming a 21st Century Economic

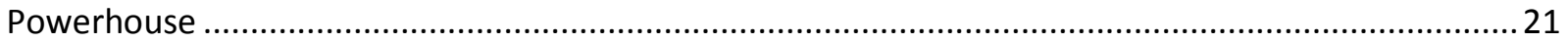

$4.4 \quad$ The Market Opportunity for Energy Improvements.............................................................2 21

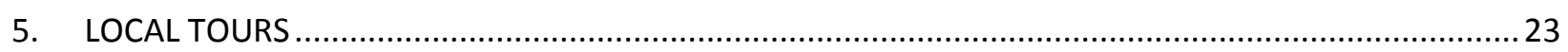

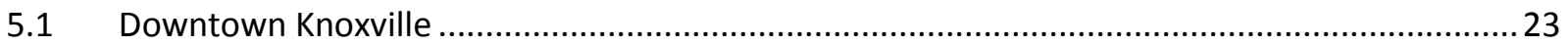




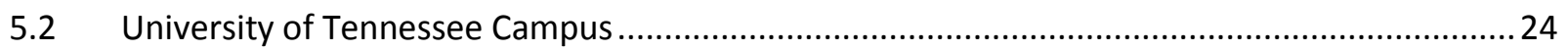

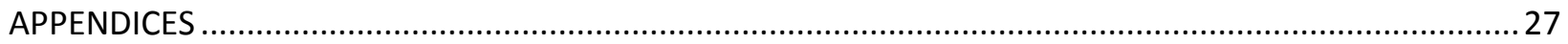

Appendix A: 3rd Annual Southeast Sustainability Summit Program ..................................................2 27

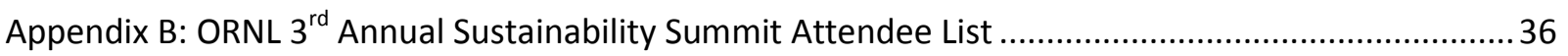

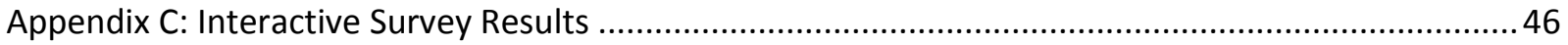

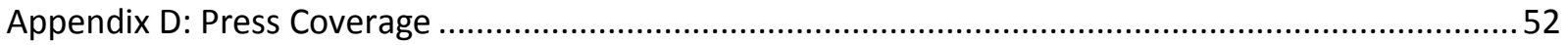

\section{TABLE OF FIGURES}

Figure 1: ORNL's Herb Debban opens the Sustainability Summit....................................................... 2

Figure 2: Molly Cripps (TDEC) provides overview of the Tennessee Energy Education Initiative ................ 3

Figure 3: Melissa Lapsa (ORNL) leads discussion panel of SSG founding members ................................ 7

Figure 4: Jennifer MacDonald provides an overview of DOE's sustainability efforts ................................ 8

Figure 5: Keynote speaker Mike Vandenbergh discusses keys to understanding drivers of human

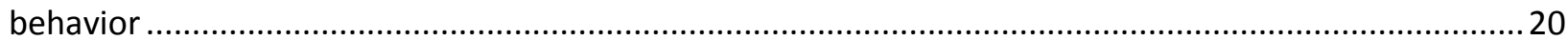

Figure 6: The Downtown Knoxville tour includes viewings of the LEED ${ }^{\circledR}$ Silver Certified Convention Center, the LEED ${ }^{\circledR}$ Silver Certified Transit Center, and the Knoxville Coliseum's solar-assisted EV charging

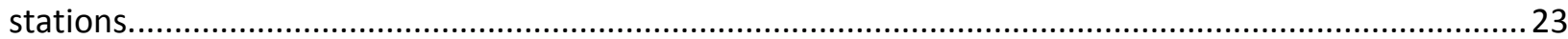

Figure 7: The University of Tennessee tour consisted of Living Light House, the Agriculture Campus' EBike Program, and the Agriculture Campus' solar-assisted EV charging stations. 


\section{INTRODUCTION}

\subsection{Summit Overview / History}

Sustainability took center stage with over 250 members of government, business, industry, utilities and academia meeting in downtown Knoxville on August 21-22, 2013 for the $3^{\text {rd }}$ Annual Southeast Sustainability Summit. Organized by Oak Ridge National Laboratory (ORNL) and the Tennessee Department of Environment and Conservation (TDEC) Office of Energy Programs and its partners in the Tennessee Energy Education Initiative (TEEI), the Southeast Sustainability Summit gave institutions, businesses, and industry the opportunity to learn about and promote sustainability efforts in all sectors.

Partners of the Tennessee Energy Education Initiative, including the City of Knoxville, the Tennessee Chamber of Commerce \& Industry, Pathway Lending, the Industrial Energy Efficiency Network, the Shelton Group, and others worked with ORNL and TDEC to plan and facilitate the event. Sixteen organizations sponsored the event:

- Advanced Energy

- Advantage Innovations

- ARiES Energy

- Automated Energy

- Baker, Donelson, Bearman, Caldwell \& Berkowitz, PC

- $\mathrm{CH} 2 \mathrm{M}$ Hill

- Clean Line Energy Partners

- Del Mar Lighting, LLC
- ET Competes!

- LubriCorp

- Piedmont Natural Gas

- Rhoades Car

- SRA International

- Stites \& Harbison PLLC

- TRANE

- University of Tennessee

Facilitated by government actions and initiatives such as Executive Order 15314 of $2009^{1}$, sustainability, or the practice of meeting current needs without compromising the ability of future generations to meet their own needs, has become a nationwide movement. Sustainability looks at issues holistically, balancing environmental, economic, and social priorities and objectives.

The Southeast has been identified as the fastest growing region in the country by the Environmental Protection Agency, but it continues to trail the nation with respect to sustainability activities. (1) As the fastest growing region, however, the Southeast has an opportunity to significantly further national sustainability efforts by incorporating sustainable practices into its growth. The $3^{\text {rd }}$ Annual Southeast Sustainability Summit provided a forum for stakeholders to share their progress in enhancing energy

\footnotetext{
${ }^{1}$ EO 15314 sets sustainability goals for Federal agencies and focuses on making improvements in their environmental, energy and economic performance. The Executive Order requires Federal agencies to set a 2020 greenhouse gas emissions reduction target within 90 days; increase energy efficiency; reduce fleet petroleum consumption; conserve water; reduce waste; support sustainable communities; and leverage Federal purchasing power to promote environmentally-responsible products and technologies.
} 
efficiency, sustainable transportation, and implementing energy conservation and smart growth measures.

At the conclusion of the summit, attendees had the opportunity to take a tour of either sustainable development activities by the City of Knoxville or sustainable housing and transportation projects undertaken by the University of Tennessee-Knoxville. The city tour included the LEED Silver Certified Convention Center and Transit Center and the solar-assisted electric vehicle (EV) Charging Stations at the Knoxville Coliseum. On the UT campus tour, participants saw the Living Light House, which was designed for the U.S. Department of Energy (DOE) 2011 Solar Decathlon competition, the campus E-bike program, and solar-assisted EV charging stations.

The Summit also served as a launch platform for the TEEl's E.D.G.E. Project to "Educate (consumer) regarding phantom loads and the impact they have on electricity usage, Discover where unnecessary "phantom" plug loads exist in the home or place of business, Gather data using a Kill-A-Watt ${ }^{\circledR}$ Meter, and Execute a plan to eradicate phantom loads." During the two-day proceedings, the TEEl distributed more than 50 Kill-A-Watt ${ }^{\circledR}$ meters to Summit attendees who pledged to report their findings as part of their participation in the project.

The full agenda for this event can be found in Appendix A.

\subsection{Opening \& Welcome}

This year marked the first time in its three year history that the Southeast Sustainability Summit was not held on ORNL's campus. Over 250 participants gathered at the Holiday Inn Downtown Knoxville at World's Fair Park to discuss and learn about sustainability. The majority of attendants were from the business community (39\%), while the remainder hailed from industry (13\%), education (12\%), the federal government (11\%), utilities (8\%), state government (6\%), non-profits (6\%), and county/municipal government (5\%). ORNL's Herb Debban opened the Summit, urging attendees to make the Southeast a center for sustainability. Debban informed the audience that Knoxville provides an ideal backdrop for the Sustainability Summit as it is the fastest growing metropolitan area for green jobs in the country. Over the past 17 years, the city government has succeeded in reducing its carbon footprint by $17 \%$.

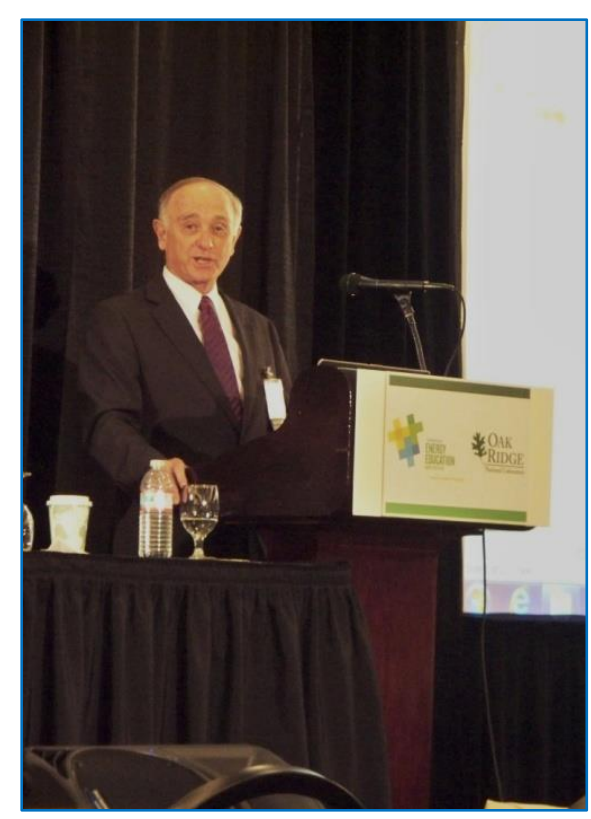

Figure 1: ORNL's Herb Debban opens the Sustainability Summit 
Knoxville Mayor Madeline Rogero followed Debban's opening by providing welcoming remarks to Summit participants. Mayor Rogero concurred with Debban's message of supporting energy conservation and efficiency initiatives, and she cited several ways that the City of Knoxville is currently implementing such practices, including:

- Single-stream recycling;

- Urban Wilderness initiative;

- An energy savings performance contract (ESPC); and

- Transportation programs, such as installation of EV infrastructure, and car-sharing.

Mayor Rogero also outlined Knoxville's green building efforts. The City recently constructed its first government building to earn a Leadership in Energy and Environmental Design (LEED) Silver certification: the Knoxville Area Transit center. Also achieving LEED Silver status is the Knoxville Convention Center. Green building is part of Knoxville's overall effort to reduce its carbon emissions from the city government and from the community by $20 \%$ by 2020 . Mayor Rogero expressed excitement to be a part of this conference so that she and colleagues could learn from this group of stakeholders, including: industry executives, the public sector, educators, researchers, community action agencies, urban planners, utilities, business leaders, and non-profits. (2)

ORNL Director Dr. Thom Mason demonstrated his personal commitment to sustainability during his opening remarks. For example, he drives an EV and recently installed a cool roof on his home. He continued by explaining that ORNL has used its role as the leading institute for clean energy research

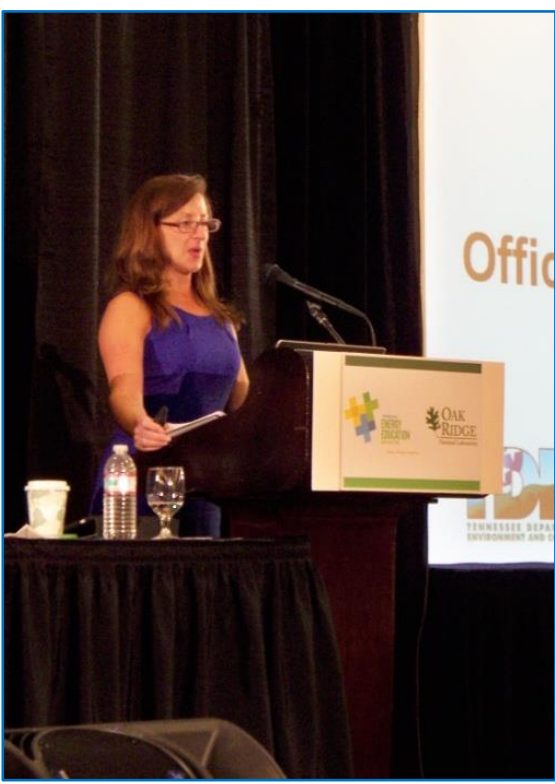

Figure 2: Molly Cripps (TDEC) provides overview of the Tennessee Energy Education Initiative and development (R\&D) to establish a new organization, the Southeast Sustainability Group. This is a non-profit aimed at accelerating the implementation of sustainability in the region. Dr. Mason noted that the inaugural Sustainability Summit in 2011 produced a vision for regional progress, and through continued collaboration the Southeast can make use of this new framework moving forward.

\section{Following Dr. Mason, Molly Cripps of TDEC Office of Energy} Programs provided an overview of the TEEI, which launched in the Spring of 2013 with funding from DOE and the American Recovery and Reinvestment Act (ARRA). TDEC Office of Energy Programs used the same source of funding to establish the West Tennessee Solar Farm, a 5-MW facility which began operating last year, and to create the Tennessee Solar Institute, an initiative to support the State's growing solar industry by providing grants to accelerate solar installation projects. (3) 
During her opening, Ms. Cripps announced the launch of TEEl's new initiative, the E.D.G.E. Project, an outreach and awareness campaign to reduce "phantom loads." As part of this initiative, TDEC's Office of Energy Programs will distribute over 200 Kill-A-Watt ${ }^{\circledR}$ meters to Tennessee residents so they may measure the phantom loads of electronic equipment or appliances. Once these loads have been established, participants outline the energy conservation measures they plan to undertake to reduce those loads. Participants must then pass the Kill-A-Watt ${ }^{\circledR}$ meter on to someone else. The Office of Energy Programs intends to follow up with each participant at 6 month and 1 year intervals in an effort to collect data regarding behavioral changes and the impact such changes have on energy consumption. More information on the program may be found at www.tnenergy.org. 


\section{PLENARY SESSIONS}

\subsection{Energy Check-up - Interactive Survey}

Rick Marsh of the Industrial Energy Efficiency Network conducted an informal, multiple choice survey on the first day of the Summit to gauge the level of commitment and activity by organizations to conserve and manage energy. Over half of the respondents said their company or agency had an energy plan or policy in place, had completed energy assessments of their facilities, and had at least one energy efficiency project underway. The survey revealed financing to be the main barrier to energy efficiency by $48 \%$ of respondents, followed by an administration that does not consider energy conservation a high priority, with $22 \%$ of respondents. The full results of this survey are available in Appendix B.

\subsection{Road to Funding: ROI Analysis \& the Navigation of Funding Options}

As alluded to in Section 2.1, one of the largest barriers to energy conservation and energy efficiency facility upgrades is high capital costs, lack of available funds, and limited payback periods. Methods for overcoming these barriers, from the perspective of the financial, business, and R\&D sectors, include Property-Assessed Clean Energy (PACE) programs, energy saving performance contracts (ESPCs), and low-interest loans.

Energy efficiency projects may be funded through publicprivate partnerships involving property owners,

SPEAKERS

- Ben Taube, President BLT Sustainable Energy

- Julia Kelley, Group Leader, Oak Ridge National Laboratory

- Clint Gwin, President, Pathway Lending governments, and local trade groups. By using PACE programs, consumers can obtain up to $10 \%$ of the fair market value of their property from the local government in order to implement energy efficiency projects. PACE projects are becoming increasingly popular because they address the key financial barriers and spur local collaboration. Although PACE loan programs are gaining momentum, enabling state legislation is still needed in some areas of the Southeast. Currently only Florida, Georgia, Louisiana and North Carolina have enacted legislation in the Southeast to authorize PACE financing (4). BLT Sustainable Energy's Ben Taube provided examples of successful PACE projects in his presentation, including the Palm Desert and Sonoma County Energy Independence Programs in California and the Long Island Green Homes effort in New York.

ESPCs, according to Julia Kelley (ORNL), offer a second financing option utilized primarily by the public sector. They enable government agencies to perform budget-neutral energy efficiency upgrades to facilities by leveraging the cost savings of the energy improvements as a means to repay the upfront costs of facility upgrade(s). These contracts allow organizations which may not have the available capital 
to implement energy upgrades without any up-front costs. Kelley lists a number of energy conservation measures that can be implemented through an ESPC: energy management control systems, building envelope technology, lighting, and distributed generation. DOE's Federal Energy Management Program (FEMP) supports the use of ESPCs and has developed special contracts with energy savings companies (ESCO) for all federal agencies to use. FEMP also offers renewable energy and advanced technologies planning and assistance to federal sites, along with ESPC training. As exhibited in Kelley's presentation, a number of ESPC projects have been performed in the Southeast. One example cited was Appalachian State University's $\$ 16.5$ million project to upgrade its heating, ventilation, and air-conditioning systems (HVAC), along with its lighting, and to install water conservation measures. A listing of legislation that supports ESPCs in southeastern states is available at http://web.ornl.gov/info/esco/legislation/newesco.shtml.

Clint Gwin explained how Pathway Lending provides low-interest energy efficiency and renewable energy loans to businesses in Tennessee. Under their program, businesses and organizations can borrow $100 \%$ of the money needed for energy efficiency or renewable energy projects, removing the barrier of high initial project costs. So far, $80 \%$ of the energy upgrades the company has facilitated have been for lighting retrofits. Pathway Lending began exploring the energy efficiency and renewable energy market in 2009 and is now expanding its energy program to include multi-family and low-income communities.

\subsection{Southeast Sustainability Group: Agents of Change}

As Melissa Lapsa of ORNL explained, DOE and ORNL are working to create a new approach to energy consumption and energy savings. With over 4,000 employees and students working on campus, ORNL plans to integrate sustainability into the employee culture, just as they have done with security and safety. They have implemented efficiency measures in a number of buildings on campus,

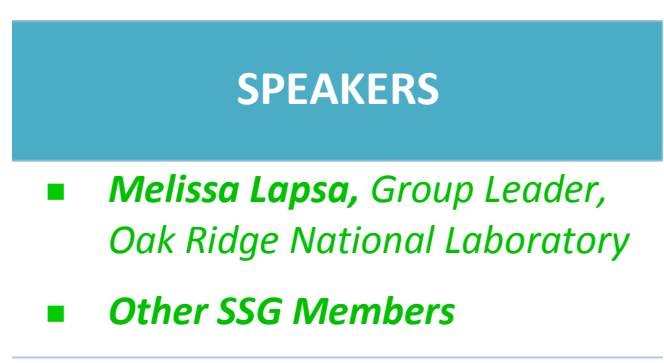
including the MAXLAB facility. The "Susie So Sustainable"

feature was created to keep employees informed of simple energy-saving measures of which they may not be aware. ("Susie" is an animated character and her sustainability message was conveyed to staff and guests through a video message which was posted on the ORNL Sustainable Campus website and distributed electronically throughout the ORNL campus.)

As part of an effort to work sustainability into the culture of the Southeast, ORNL is partnering with six other institutions in the non-profit Southeast Sustainability Group (SSG) to promote sustainability measures in this region. Representatives from each of the founding institutions talked about why their organization chose to be part of the SSG and what they hoped to gain from it. With an initial membership list including Black Bear Solar Institute, Clark Atlanta University, Indian River State College, Nissan, ORNL, Tennessee Valley Authority, and the University of Tennessee, the mission of the SSG is to "advance sustainability through the understanding, development, and implementation of projects on a large and widely spread scale across the Southeast United States." With 73\% of the Southeast's power coming from fossil fuels, the region stands to benefit from clean energy and sustainability initiatives that 
reduce overall energy consumption (5). Specific issues the SSG is evaluating include the high number of vehicle miles traveled in the region and the limited availability of regional public transit.

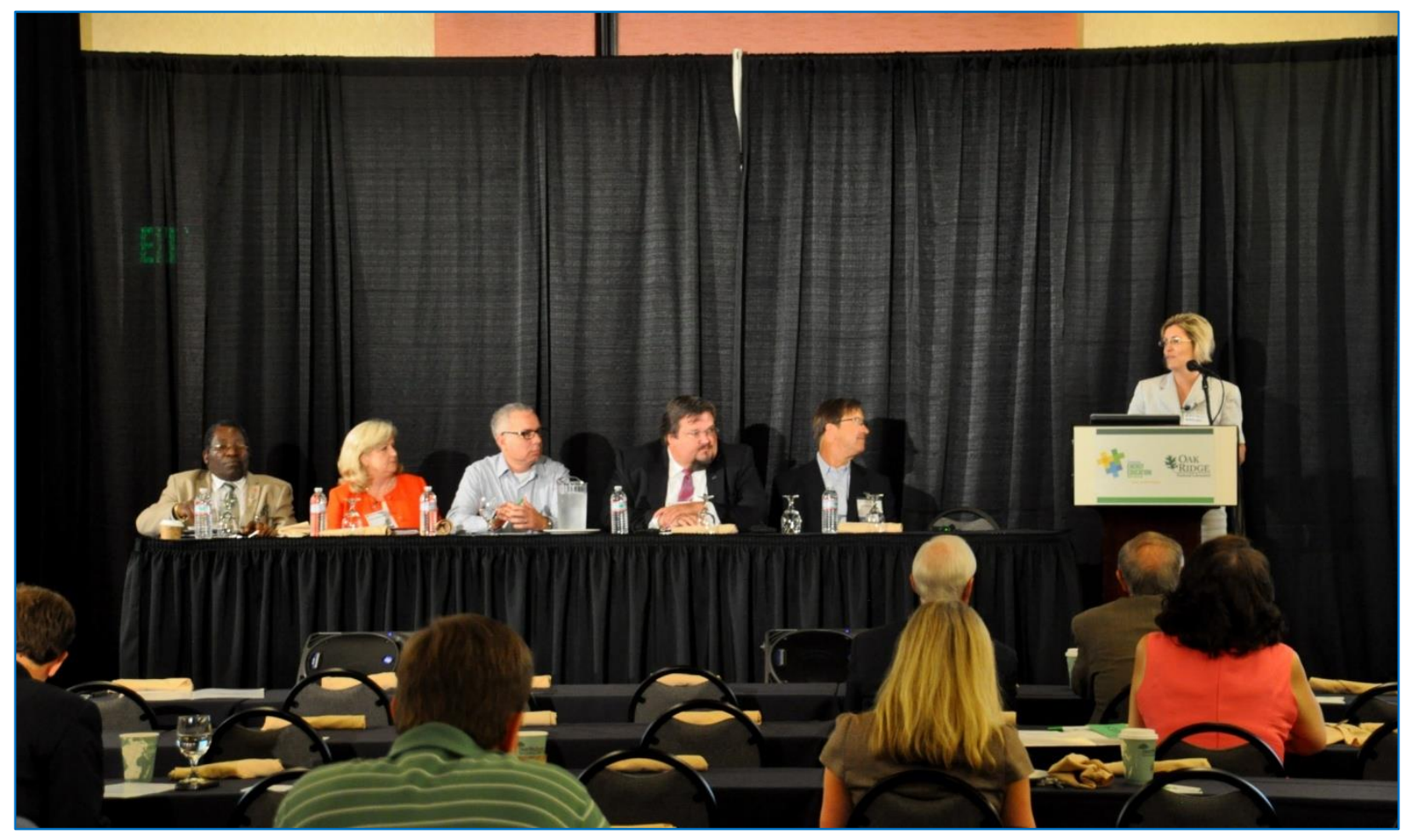

Figure 3: Melissa Lapsa (ORNL) leads discussion panel of SSG founding members

\subsection{The Department of Energy's Role in Sustainability}

Facilitated and inspired by Executive Order 15314, entitled

"Federal Leadership in Environmental, Energy, and Economic Performance," Jennifer MacDonald of the U.S. Department of Energy (DOE) indicated that governments across the country have initiated energy conservation and clean energy programs. In leading by example, DOE has undertaken a number of sustainability efforts that have helped the agency reduce its energy use and emissions

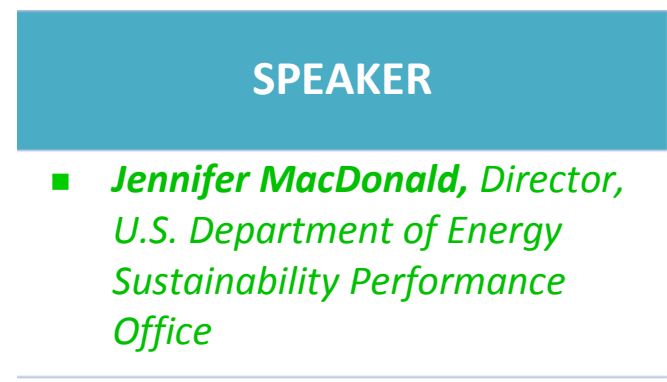
and, in turn, is meeting or exceeding its goals in the reduction of greenhouse gas emissions, energy intensity, and water intensity. Additionally, DOE has increased its use of renewable energy and alternative fuels, and has met or exceeded its goals for these categories.

While DOE has decreased its usage of petroleum and increased its percentage of high-performance sustainable buildings, MacDonald noted that the agency is not on track to meet its FY 2020 objective of 
lowering petroleum use by $30 \%$ compared to an FY 2005 baseline; similarly, DOE is not on track to meet its FY 2015 objective to have 15\% of facilities over 5,000 gross square feet to be high-performance sustainable buildings. In the next few years, DOE looks to increase the percentage of renewable energy projects, enhance building sustainability, increase its use of performance contracting, and employ measurement and verification to track its progress.

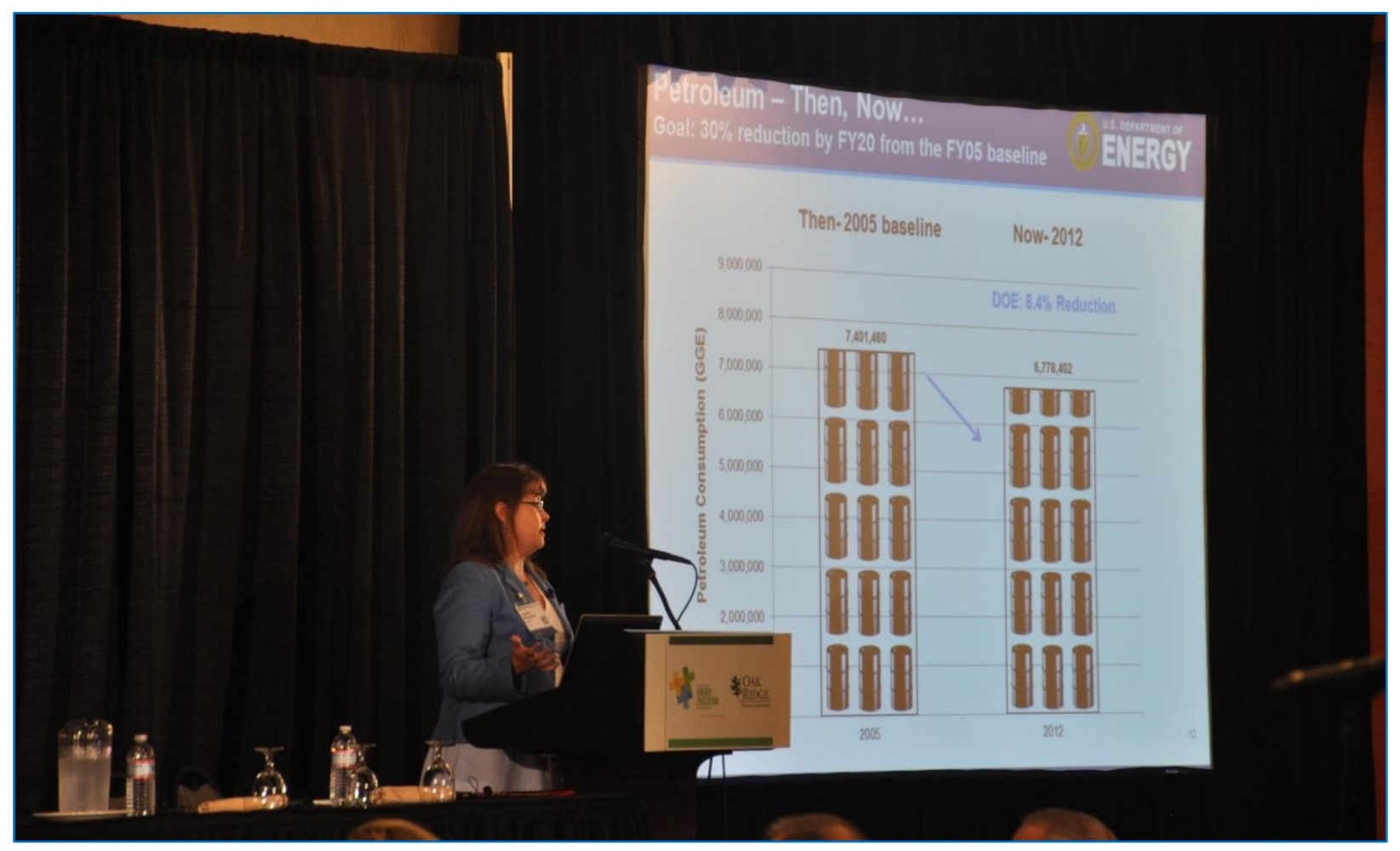

Figure 4: Jennifer MacDonald provides an overview of DOE's sustainability efforts 


\section{BREAKOUT SESSIONS}

\subsection{Qualified Energy Conservation Bonds (QECBs) Part 1 - Overview of Tennessee Program \& Best Practices}

QECBs are a fairly new low-interest financing mechanism, available as a tax credit bond or as a direct subsidy bond that may be issued by eligible entities. TDEC's Katie Southworth started out the session by defining QECBs, how they work, how they were created, and who utilizes them. QECBs are specifically allocated to finance qualified renewable energy, energy efficiency, and energy conservation capital projects. The federal government

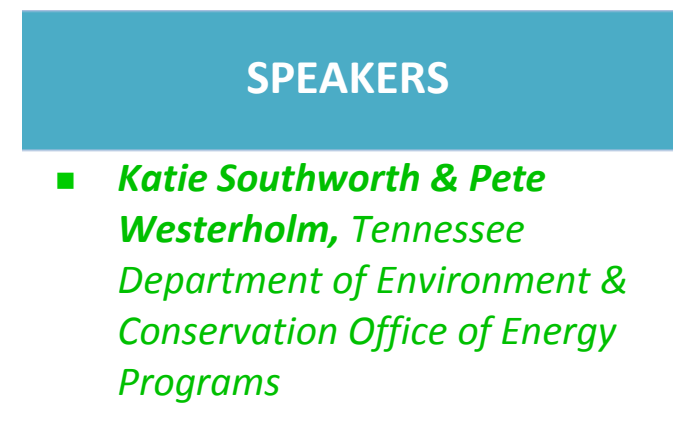
allots $\mathrm{QECB}$ authority to each state, and the state in turn may allocate amounts of the total QECB volume to qualified issuers. Tennessee has $\$ 64.7$ million in QECB authority; some of this amount has been utilized by eligible cities, and the remainder will be available for local governments and public universities through a competitive sub-allocation process. TDEC's Pete Westerholm discussed this process, and described best practices and case studies of QECB utilization from around the country. In Tennessee, most efforts focus on reducing energy consumption in public buildings. (6)

The cities of Boulder, Colorado and Foley, Alabama were given as examples where QECBs were used to complete projects through energy performance contracts. In Boulder, proceeds from QECBs are helping the City reduce its carbon footprint by over $450 \mathrm{MT}$ /year and reduce its electricity consumption by $28 \%$. Water and natural gas consumption will be lowered as well. In Foley, a citywide energy management system and communication network was implemented, along with HVAC and lighting upgrades, solar panels, and rainwater control. The City was able to lower its utility costs by $33 \%$ as a result.

\subsection{Qualified Energy Conservation Bonds Part 2 - Bond Financing \& Eligible QECB Projects}

Following the introduction to QECBs given by TDEC in Session 1, George Masterson described the three approaches the Federal Government has used for QECBs and provided insight on which strategies have proven most successful. The U.S. Government has subsidized local and state bonds through tax exemptions, tax credits, and direct payments. Of the three approaches, direct payment bonds have proven to be the most popular, one example being the Build America Bonds. With direct payment bonds, the U.S. Treasury makes regular subsidy payments directly to the issuer of the bonds. QECBs may be used to

SPEAKERS

- George Masterson, J.D., Bass, Berry, \& Sims

- Elizabeth Bellis, Energy Programs Consortium

- Glenn Barnes, UNC School of Government Environmental Finance Center 
finance both public and private projects; however, no more than $30 \%$ of a state's aggregate volume allocation may be used for private activities. (6)

Elizabeth Bellis of the Energy Programs Consortium then described how QECBs have been used to fund a variety of projects, the utilization of the bonds in different regions of the country, and potential barriers to implementing QECB projects. To date, 79\% of QECBs are used for energy efficiency projects, followed by $11 \%$ for Green Communities projects and $10 \%$ for renewable energy projects.

The Southeast received the largest percentage of QECB allocations, 24.3\%, but has utilized the smallest portion of its allocation, 7.6\%. A number of Southeastern states have yet to issue QECBs. To date, four Southeastern states have issued QECBs, and all of them have supported energy efficiency projects. QECBs may be used towards energy reduction projects in public buildings -- these projects must result in a $20 \%$ reduction in energy consumption. Uncertainty may arise in the design of such projects where the exact savings from efficiency upgrades cannot be specified in advance of project completion. As a best practice, certification from an engineer should be obtained ahead of time, stating that the engineer expects to observe at least $20 \%$ energy savings on the project.

While QECB projects are not prevalent in the Southeast, successful QECB projects are being completed across the country. For example, Glenn Barnes of the UNC School of Government Environmental Finance Center discussed upgrades to a Pennsylvania jail in which Allegheny County had positive cash flow in the first year of the project. The second project Barnes referenced involved the replacement of streetlights in Surprise, Arizona, where street and baseball field lights were upgraded using a 15-year QECB issue. The energy savings are expected to surpass the principal and interest payments of that project.

\subsection{Driving Toward Sustainable Transportation}

As Scott Curran explained, ORNL is interested in advancing sustainable transportation out into the community and is working with businesses to develop and accelerate transportation concepts and technologies in the next 15 years. Curran's Research and Development group partners with the ORNL Sustainable Campus Initiative in this effort. ORNL also collaborated with DOE and the U.S.

Environmental Protection Agency (EPA) to launch the FuelEconomy.gov website in 1999, which provides extensive resources to consumers on current and upcoming vehicle models.

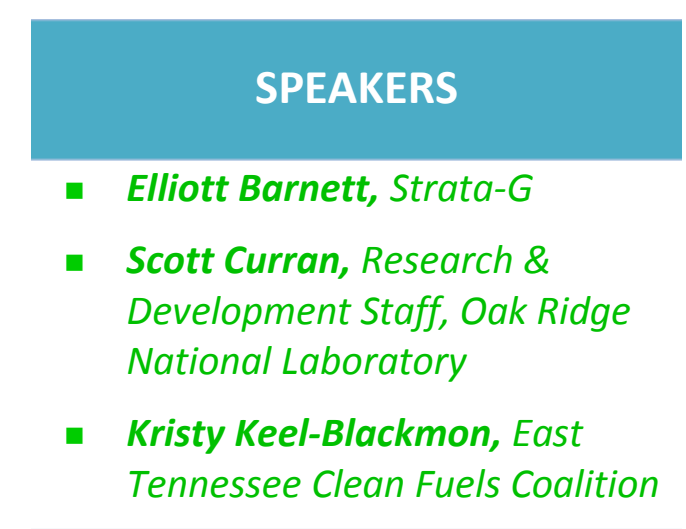

Elliott Barnett of technical advisory firm Strata-G Solutions spoke of the company's interest in promoting natural gas as a vehicle fuel because it is safe, domestic, relatively inexpensive, and is cleaner than gasoline. According to Barnett, the use of natural gas vehicles has ramped up quickly in specific fleet types: in the United States, $40 \%$ of new garbage trucks and $16 \%$ of new transit buses run on compressed natural gas. The missing piece for this fuel, Barnett explained, is infrastructure; a sufficient network of 
natural gas fueling stations does not exist. In response to a question on funding for natural gas stations, the speakers commented that there are Diesel Emission Reduction Act grants available, but ultimately sufficient demand is necessary for a station to be financially viable.

Sevier County is an example of a local entity that has started its own CNG fleet and is in the process of constructing a CNG filling station. Meanwhile, other groups, such as the East Tennessee Clean Fuels Coalition, have been fielding numerous questions regarding the vehicles and technology. While officially unbiased with respect to transportation fuels and technologies, Kristy Keel-Blackmon of the East Tennessee Clean Fuels Coalition noted that most of the inquiries to the organization concern natural gas. East Tennessee Clean Fuels is pursuing efforts in other areas and has partnered with ORNL and Knoxville schools on an idling reduction initiative. Other ongoing projects that include the support of the Coalition include facilitation of truck stop solar electrification and coordination with DOE on the EV Project.

\subsection{Changing Behaviors in the Workplace - Employee Engagement}

According to Jeff Rehm, Sustainability Manager of Grainger, sustainability is becoming an increasingly larger part of organizational corporate strategies and practices. Businesses and institutions are integrating the practice through numerous different methods. Grainger, for example, has implemented a step-by-step process to determine the best path for integrating sustainability into their business. The industrial supply retailer began by surveying their employees on their knowledge of sustainability and, more specifically, Grainger's sustainability efforts. Using the feedback gathered, a Sustainability Strategic Framework was developed with seven end goals and objectives, including team engagement, transportation efficiency, and responsible resource use. To ensure these objectives are met, Grainger

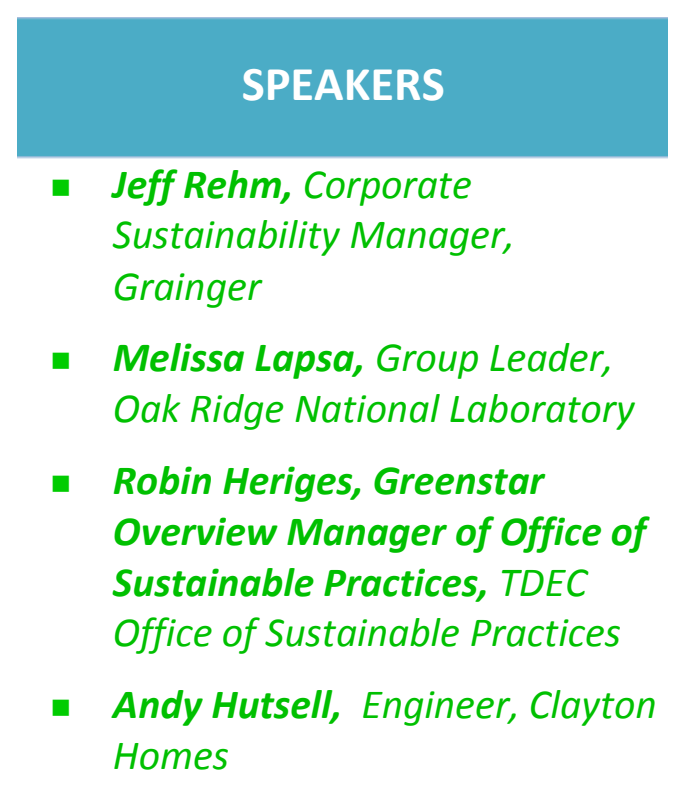
is in the process of introducing a Green Ambassador at each of its facilities in the United States, whose role is to implement energy conservation and sustainability measures on site.

The sustainability efforts employed by Clayton Homes focus more on the materials, supplies, and technologies used in the construction of the homes. Clayton Homes are factory built, which reduces construction and minimizes the amount of waste created. An employee recycling award system allows staff to experience a direct benefit from recycling. The company also promotes energy-efficient materials in its homes, such as thermal pane windows and compact fluorescent lighting (CFL). In the next five years, the company would like to align with a certification program that will enhance the quality of its homes. 
ORNL has employed a different tactic by engraining sustainability into campus culture through its Sustainable Campus Initiative. Melissa Lapsa noted that in the past, the Lab has launched similar largescale initiatives for safety and security. A number of green transport options are available on the expansive campus, including EV charging locations and a bike share program. The Sustainable Campus Initiative has also launched a new employee awareness campaign in addition to its overall outreach efforts.

TDEC's Tennessee Green Star Partnership serves a similar role to ORNL's Sustainable Campus Initiative. Formerly the Tennessee Pollution Prevention Partnership, the Green Star Partnership (now with sustainability in its scope) is an environmental leadership group whose goal is to celebrate the sustainable initiatives of its members and to facilitate the implementation of new initiatives. When joining the partnership, companies can opt for the Energy Management System Track (designed for larger companies) or the Sustainable Business Track (designed for smaller companies). TDEC outlined the three advancement levels companies can attain: One Star, Two Star, and Three Star Partnerships, with the level of effort required increasing with the level number. The group works to foster collaborations between Green Star partners, and last year the collaborations led to \$1.1 million and over $20,000 \mathrm{MT}$ of $\mathrm{CO}_{2}$ eq. in savings.

\subsection{Institutes for Sustainable Research, Development \& Deployment}

After exploring the ways in which sustainability is being assimilated into employee culture, the scope of this session was expanded to the institutional level with details on the practices that Georgia Tech and ORNL have undertaken to achieve sustainability. Howard Wertheimer explained that Georgia Tech promotes sustainability at every level, including landscape plans, space management and building design. Researchers at the school were engaged in the planning process. To support these new design efforts, the school set up an organization called Georgia Tech Facilities, which sells bonds to raise funds for buildings and facilities.

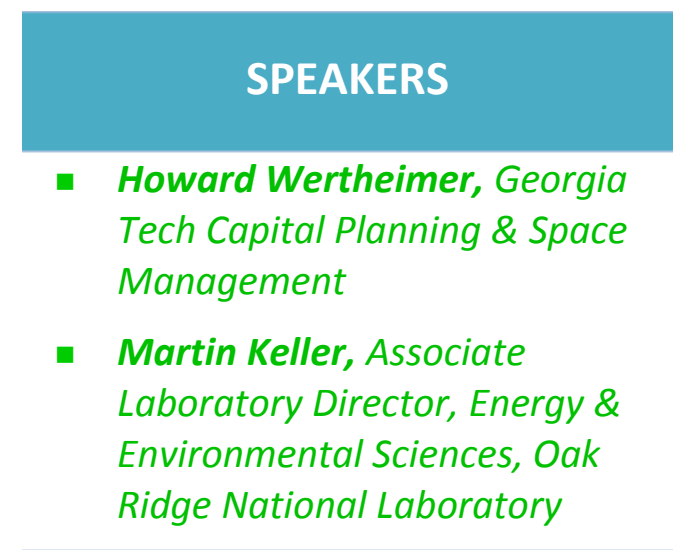
The National Institute of Science \& Technology has also provided a significant amount of funding for energy conservation and energy efficiency design in campus facilities. Wertheimer identified communication and collaboration as the biggest challenges to integrating sustainability across institutions.

ORNL's R\&D efforts were also showcased. Martin Keller of ORNL described the facets of sustainability that ORNL is researching and some of the technologies they are investigating within the facets of sustainable transportation, energy efficiency in buildings and advanced manufacturing. For sustainable transportation to be successful, he noted that industry needs to integrate across electrification, efficiency, alternative fuels and intelligent systems. Current advanced transportation endeavors at the Lab include the EV Project and wireless power transfer technology. 
With buildings and advanced manufacturing, ORNL is developing cost-effective, energy-efficient construction designs and improving performance through integrated sensors and controls and highefficiency equipment and appliances. $R \& D$ facilities that are available to interested organizations for collaborative R\&D include the Manufacturing Demonstration Facility (MDF), the Carbon Fiber Technology Facility (CFTF), the National Transportation Research Center (NTRC), and the Building Technologies Research and Integration Center (BTRIC). Through collaboration with industry, a concentrated effort can be placed on discovering "the next big thing," with a goal of bringing more sustainable technologies to the market.

\subsection{Energy Management Case Studies - A Look at Three Unique Industry Sectors}

Energy management is a holistic approach that businesses can use to better identify and target opportunities to conserve energy and materials. Some industries with specialized facilities have created independent organizations to support the transition of these specialized facilities to more sustainable, energy-efficient practices.

The Healthier Hospitals Initiative (HHI), as Christopher Bodkin explained, looks to improve community health by helping hospitals assess their impact on the environment and how their energy usage may indirectly contribute to a rise in disease. A total of 500 hospitals are already

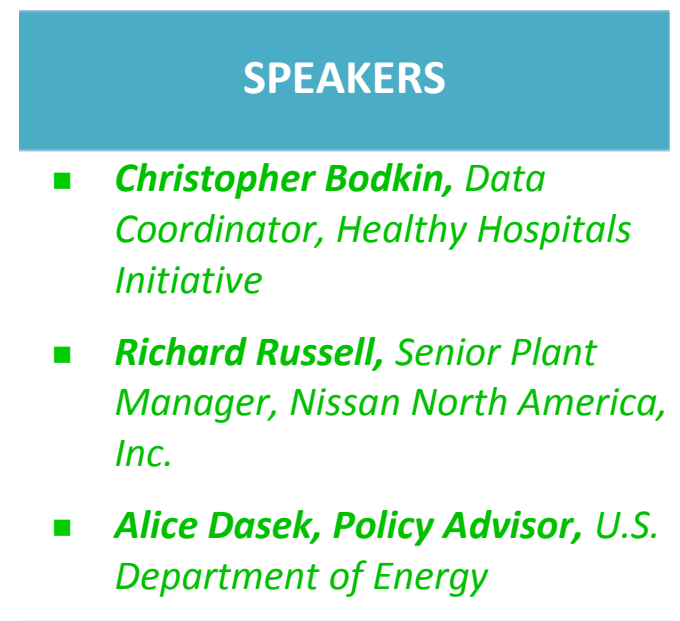
engaged; over time, the program hopes to reach 2,000 hospitals. Reduction goals for Level 1, 2, and 3 greenhouse gas emissions help institutions to measure and quantify this environmental impact. Examples of energy efficiency and conservation promoted by $\mathrm{HHI}$ include engaged leadership, less waste, safer chemicals, smarter purchasing, and leaner energy. More information on this program is available at http://healthierhospitals.org/. (7)

As with healthcare, the majority of energy usage by businesses and institutions revolves around their facilities. At Nissan, the automaker has established a Green Program. According to Richard Russell, Nissan has selected 2008 as its baseline year and is implementing an energy management system to reduce energy use and emissions with respect to this baseline. With this system, Nissan is better equipped to find hidden waste, validate savings, and improve design and procurement. All manufacturing plants are enrolled in the DOE Better Plants Initiative and have been ENERGY STAR ${ }^{\circledR}$ certified. At its Smyrna, Tennessee plant, Nissan has consolidated all plants under one roof to reduce its energy footprint. (8)

Nissan and other participants in the DOE's Better Plants Initiative are working to reduce their energy consumption $25 \%$ over 10 years. The Better Plants Initiative, as explained by Alice Dasek of DOE, is designed to support companies in this effort through two programs: the Better Buildings Challenge 
(BBC) and Better Buildings Alliance (BBA). The BBC facilitates retrofit projects, helps businesses make their data more transparent, and helps share successful energy management implementation models. Over 120 organizations, including seven in the Southeast, have pledged 2 billion square feet of space to the BBC. The BBA focuses on energy efficiency efforts and gives its members the goal to lower their energy usage by $2 \%$ each year. Working groups within these programs look to accelerate the adoption of clean energy strategies and mechanisms in the marketplace.

\subsection{Lighting Upgrades - The Gateway to Energy Efficiency}

Lighting can play a significant role in increasing a building's energy efficiency. Recently, the Knoxville Convention Center upgraded its lighting system as part of its effort to become the state's first LEED-certified convention center. Jason Bourgoyne of the Knoxville Convention Center discussed the organization's unique challenge of selecting a mixture of light-emitting diode (LED) and induction lights that were needed to accommodate the wide range of lighting features (e.g., theatrical and dimming abilities) and varying ceiling heights of the Center. In other words, certain energy-efficient lighting routes, such as $100 \%$ LED, were not an option.

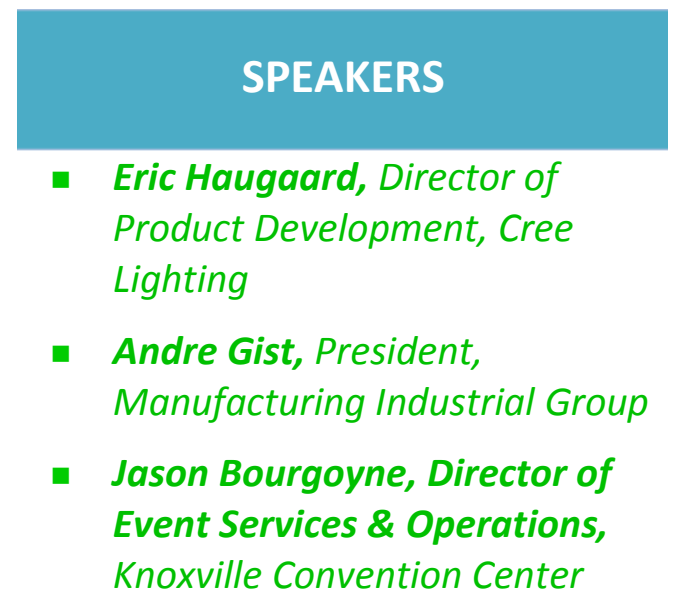

During the question and answer session, panelists shared information on other common challenges. For instance, Eric Haugaard of Cree Lighting explained that light fixture upgrades quickly increase overall facility efficiency, but decision-makers often opt for the most rapid return on investment and not necessarily the best long-term value. Andre Gist of the Manufacturing Industrial Group noted that incentive programs designed to decrease the payback period of lighting upgrades makes that efficiency effort more attractive to potential consumers. If these incentive programs begin to taper off, certain superior upgrades would become a harder sell. However, the panelists noted the importance of technologies needing to stand on their own two feet without the indefinite support of incentives.

Another challenge with lighting upgrades is consumers' unfamiliarity with lighting products on the market. Haugaard recommended products with comprehensive performance data, UL approval, and strong durability and corrosion properties (if installed outdoors). Additionally, the DOE CALIPER and GATEWAY programs are good sources for identifying high-quality products.

Finally, daylight harvesting is another lighting option which is becoming increasingly easier to implement and therefore increasingly important. 


\subsection{Strategies for Efficient Water Heating \& Use}

ORNL's Roderick Jackson, moderator of the session, opened with a synopsis of how DOE is working to develop a number of different water heating technologies and methods, including advanced HPWH designs (e.g., gas-fired absorption or using $\mathrm{CO}_{2}$ as a refrigerant) and the integration of solar energy. Jackson noted that DOE has not settled on one specific R\&D path but instead sees value in investigating several avenues for advancing energy efficiency and financial savings to the consumer. The relationship between cost and efficiency will continue to be an important factor moving forward since an increase in efficiency often corresponds with an increase in cost.

The panel, comprised of Jackson and three private industry representatives, followed with brief introductions as well as overviews of their organization's efforts toward

SPEAKERS
Casey May, Federal Business
Development Director, FLS
Energy
Richard Kelso, Principal/ Chief
Technical Advisor, CaraSol
Energy
Bill Hosken, National Sales
Director, A. O. Smith
Roderick Jackson, Research \&
Development Staff Member, Oak
Ridge National Laboratory
sustainable water heating from the utility, solar energy, and manufacturing perspectives.

CaraSol, a solar energy service provider, constructs flat plate collectors for solar panels. As Chief Technical Advisor, Richard Kelso brings extensive experience to the team as supervisor of the Living Light House on the University of Tennessee campus that competed in the 2011 DOE Solar Decathlon. Regarding ideal applications for solar thermal technology, Kelso explained that commercial applications are an excellent fit as the peak hours of use correlate with peak solar collection.

A.O. Smith is one of the oldest and largest manufacturers of water heating appliances with a primary focus on commercial applications. A.O. Smith's Bill Hosken provided tips to the audience on which conditions are best suited for HPWHs. For instance, they should be located in rooms that stay within 40 and $120^{\circ} \mathrm{F}$ (i.e., avoid hot attics) and that have plenty of open room, like a basement.

Jackson closed the session by stating that in order to promote efficiency at all levels of the water heating process, ORNL utilizes a system-scale approach to integrate water heaters with other systems in the building where possible. ORNL has constructed and retrofit sixteen homes where individual appliance performance is monitored. Data from these homes and additional studies have shown that while HPWHs perform well and provide savings in Tennessee, the same results may not be realized in all regions and climates. 


\subsection{Ground Source Heat Pumps - Challenges \& Opportunities}

Geothermal heat pump (GHP) systems provide a number of benefits in comparison to conventional heating, ventilating, and air conditioning (HVAC) systems. They operate more efficiently because the temperature of the earth remains constant near the indoor air temperature of $20-27^{\circ} \mathrm{C}$, and heat pumps are most efficient when the heat source and heat sink are similar in temperature. According to John Shonder, ORNL and ASHRAE are actively researching ways to improve GHP system designs and reduce secondary loads. The organizations also strive to develop public guidance for lesser known designs.

Townsend Engineering develops hybrid GHP technologies, which Terry Townsend explained is a good match for schools because they are sized for average heating load, which typically takes place during school hours. Townsend has observed that while GHP technology would greatly

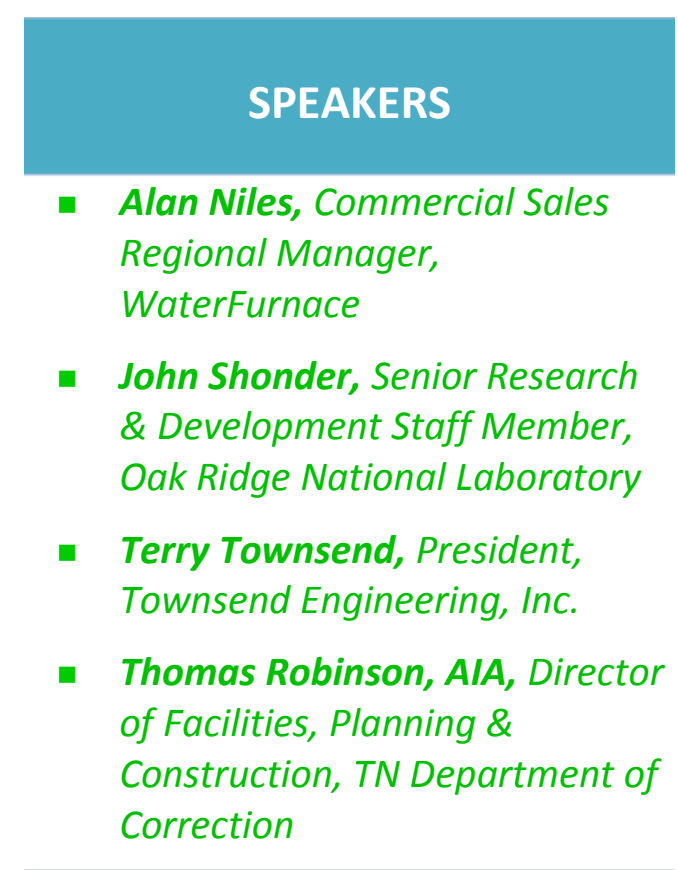
benefit schools, they often are resistant to new technologies because of the high up-front cost associated with them. Thanks to a Department of Energy grant award, however, the Environmental and Energy Study Institute was able to allot approximately $\$ 5$ million to its Hybrid Geothermal Grant Program. The program looks to develop cost effective, innovative designs for hybrid geothermal heat pump systems as well as installation guidance for K-12 school facilities. Since then, Townsend has chosen three schools in two districts to use the extra funds in an effort to provide local case studies where GHP systems have provided major improvements in cost, etc., for school systems.

Similarly, WaterFurnace has installed projects at North Royalton Middle School in Salt Lake City, Utah, and Murray High School just outside Cleveland, Ohio. Thanks to the lower operating, lifecycle, and maintenance costs of their GHP systems, the school districts were able to realize significant savings with respect to conventional HVAC systems. For its North Royalton project actual operating costs turned out to be $28 \%$ lower than projected. Murray High School saw savings of $29 \%$ from its GHP installation compared to a comparable school running a conventional HVAC system.

Tennessee's addition of a GHP system at its Department of Correction Bledsoe County Complex represents the largest single construction project in State history at a cost of \$208 million. Since the prison complex runs $24 / 7$, energy savings measures are particularly important. GHP systems incorporated at the site include space heating, space cooling, and water heating. Originally, the payback period was 19 years, but this has since been lowered to about 12 years. 


\subsection{Bike Share - A Better Way to Travel}

To open the session, overviews of the Nashville, Chattanooga, and Washington D.C. bike share programs were provided by panelists. A Question and Answer session followed.

Nashville's cycling program, as described by Kim Hawkins, was funded by the Center for Disease Control and Prevention, better known as CDC, as opposed to the more expected Transportation or Energy Departments. Consequently, the program reports its benefit in terms of health metrics. Since program inception in December 2012, participants have burned over 5.7 million calories through the program, which targets both residents for long-term use and tourists who tend to purchase one-day passes. The

SPEAKERS
Philip Pugliese, Bicycle
Coordinator, Outdoor
Chattanooga
Kim Hawkins, Urban Design
Architect, Metro Nashville
Bicycle \& Pedestrian Advisory
Committee
Bill Nesper, Vice President of
Programs, The League of
American Bicyclists
program is not just about getting people on bikes. A full bike infrastructure, which includes bicycle lanes, and educational outreach efforts are also required. Both Tennessee programs have been able to build off existing greenways networks to help establish their cycling infrastructure. Challenges for the program include hilly terrain, heat, inclement weather, access issues, privacy issues, and limited customer understanding of the various program options.

The Chattanooga area bike share has been operating for just over a year and now has 300 bikes in its program. Usage has been split pretty evenly between day-pass users and program members. The bike share targets residents and tourists with tourists purchasing about $50 \%$ of the day passes sold. Since its inception, Chattanooga's bicycling initiative has reduced $\mathrm{CO}_{2}$ emissions by 18,000 pounds, and Philip Pugliese of Outdoor Chattanooga spoke of the organization's collaboration with the City's law enforcement and driver education program to establish guidance for bike sharing. The ultimate goal of the program is to gain significant ridership to change the culture of the community.

The Capital Bike Share program in Washington D.C. has set an ambitious goal of $5 \%$ bike transportation by 2025. Bill Nesper of The League of American Bicyclists has estimated that the Capital Bike Share has reduced the number of car trips by approximately 4.4 million each year. While the D.C. area program focuses its efforts on tourists, $80 \%$ of residents have said through surveys they would patronize a bike share program.

When asked for recommendations on how to establish bike sharing programs in smaller communities, panelists noted that a very dense population, such as a city center with short commutes, is most important. Aspen, for example, has a successful program even though the city boasts only 6,000 residents. 


\section{KEYNOTE ADDRESSES}

\subsection{A Better Way - Restoring the Long-Term Economic, Social \& Environmental Health of Our Cities}

John Knott Jr. kicked off the keynote luncheon address on the first day of the conference by outlining the many problems with current and traditional approaches to city planning. Throughout his thought-provoking presentation, Knott systematically identified which pieces of the planning process are missing, which need adjusting, and how CityCraft Venture's perspective and focus incorporate

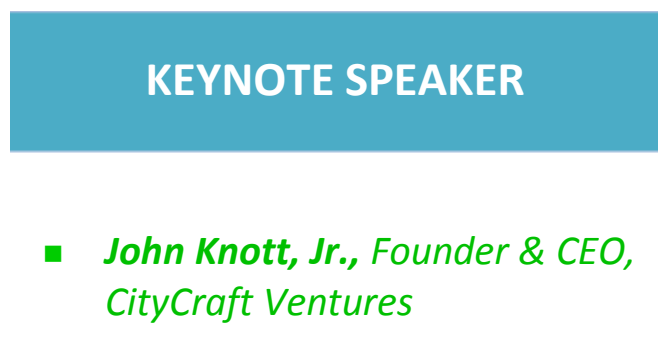
these pieces into urban planning. (9)

The CityCraft ${ }^{\mathrm{SM}}$ Process, developed by Knott, expands the current short-term thinking approach to a long-term outlook and expands the physical scope of urban planning from the city limits to encompass the city's bioregion, natural resources, and its people. According to its website, the process was "developed specifically for challenged and distressed areas within cities that have not responded to previous revitalization efforts or where these efforts have not been able to positively change the social and economic justice conditions." A blueprint is needed that is restorative, long-term, holistic, respectful of social and ecological systems, and embraces our changing 21st century culture, economy, and conditions. Knott's company puts an equal focus on environment, economics and community. (9)

Knott believes that community planning should treat the community, including each building, as a system. Cities should be built around the natural resources available in that area. Furthermore, planners need to take a bioregion focus and realize that every act they take should invest in the bioregion itself. The people of a city should be treated as a valuable resource and be used to help rebuild the region. (9)

Two recent projects by CityCraft Ventures worked to revive the communities of Dewees Island and Noisette, both in South Carolina. Dewees Island was the first profitable, sustainable community that CityCraft Ventures completed. In Noisette, CityCraft treated the City as a community-based climate system and created a new institutional framework. Its renovation was comprised of two key elements: a cultural change process and physical replanning. (9)

\subsection{Behavior Change - From Individuals to Institutions}

Bob Martineau, Commissioner of TDEC, opened this keynote session by raising an often cited argument against sustainability efforts: that people must choose between protecting the environment and growing the workforce. However, Martineau explained that numerous projects are underway in Tennessee that help disprove this claim. The City of Chattanooga is replacing streetlights with LED lighting, and the State of Tennessee has added thermal film insulation to the Tennessee Tower as energy saving measures. Another important energy efficiency initiative is the investigation of ways to reduce 
energy costs at water and wastewater facilities. Seven utility districts in the state are participating in this effort, and energy savings of $17 \%$ are predicted. Also, Tennessee Technological University, in its efforts to become a sustainable campus, has taken 44 buildings off of coal power in recent years. These project examples show that environmental conservation measures can also contribute to the local economy.

This point was reiterated by speaker Mike Vandenbergh in his keynote address on behavior change. The Vanderbilt KEYNOTE SPEAKER Law Professor argued that environmental preservation and an attractive bottom line do not have to be mutually exclusive goals. Through outreach initiatives and case studies, TDEC is helping businesses achieve both. To do this, society must integrate the concept of sustainability into both individual and institutional behaviors.

Vandenbergh began his address by describing a solar assisted EV charging station at Vanderbilt that is largely underutilized. Vandenbergh explained a number of factors as to why more drivers of EVs were not charging on campus: the relatively higher cost of charging on campus versus charging at home, time limits for using the EV charging station, and time constraints on faculty and staff to relocate their vehicles after charging. As a result, the underutilized charging stations send the wrong message that people simply do not like, or are not driving, EVs.

This example epitomized the theme that we know how to change individual/household behavior, but not how to change institutional practices. The Climate Change Research Network at Vanderbilt, of which Vandenbergh is the Director, is studying how to integrate sustainability into these processes without expecting people to make unrealistic changes to their lifestyles.

Vandenbergh's address focused on the concept of the behavioral wedge, which demonstrates the ability to significantly reduce greenhouse gas emissions through practical residential energy conservation and energy efficiency measures. These include changing driving behavior, setting laundry temperature, line drying, tuning up air-conditioning units, weatherization, and appliances. Cumulatively, research shows that these changes could reduce emissions by $233 \mathrm{MTC}$. However, the reasonably achievable emissions reduction (RAER) for these behaviors equals $123 \mathrm{MTC}$.

In order to implement new behavioral lessons, Vandenbergh argued that it is necessary to understand what drives behavior. Price is important, but it is not the only factor. Vandenbergh presented data showing that people generally follow "the law of least effort," so efficiency steps that require the least effort are generally most effective.

When the scope of behaviors is expanded to include institutions, the answers are not as clear. Issue framing and social influence play an important role in deciding institutional practices. As Vandenbergh 
noted, many industries and groups can claim they are only $1 \%$ of the problem and that environmental mandates and requirements should not apply to them. The overarching problem, however, is comprised of the sum of all these actors' emissions. Furthermore, people do not want to express opposing feelings on such issues, and if they think they are doing as the majority does, they are unlikely to act.

Vandenbergh emphasized that changes can be made without regulatory demands. Although most people assume that government will be the primary actor for major issues, broader involvement by private institutions and other non-governmental entities is needed. The Southeast has an opportunity to make a difference by implementing sustainable practices. Vandenbergh stressed that Tennessee, in particular, has relatively high electricity consumption per residential consumer, which offers a major opportunity for improvement.

Vandenbergh highlighted the lack of education or awareness in energy conservation. As an example, he presented the myth that hot water is needed to wash hands effectively. This practice wastes energy and water, since cold water is equally effective. To combat these misconceptions, Vandenbergh argued, people must be educated in a way that stimulates rational response and action.

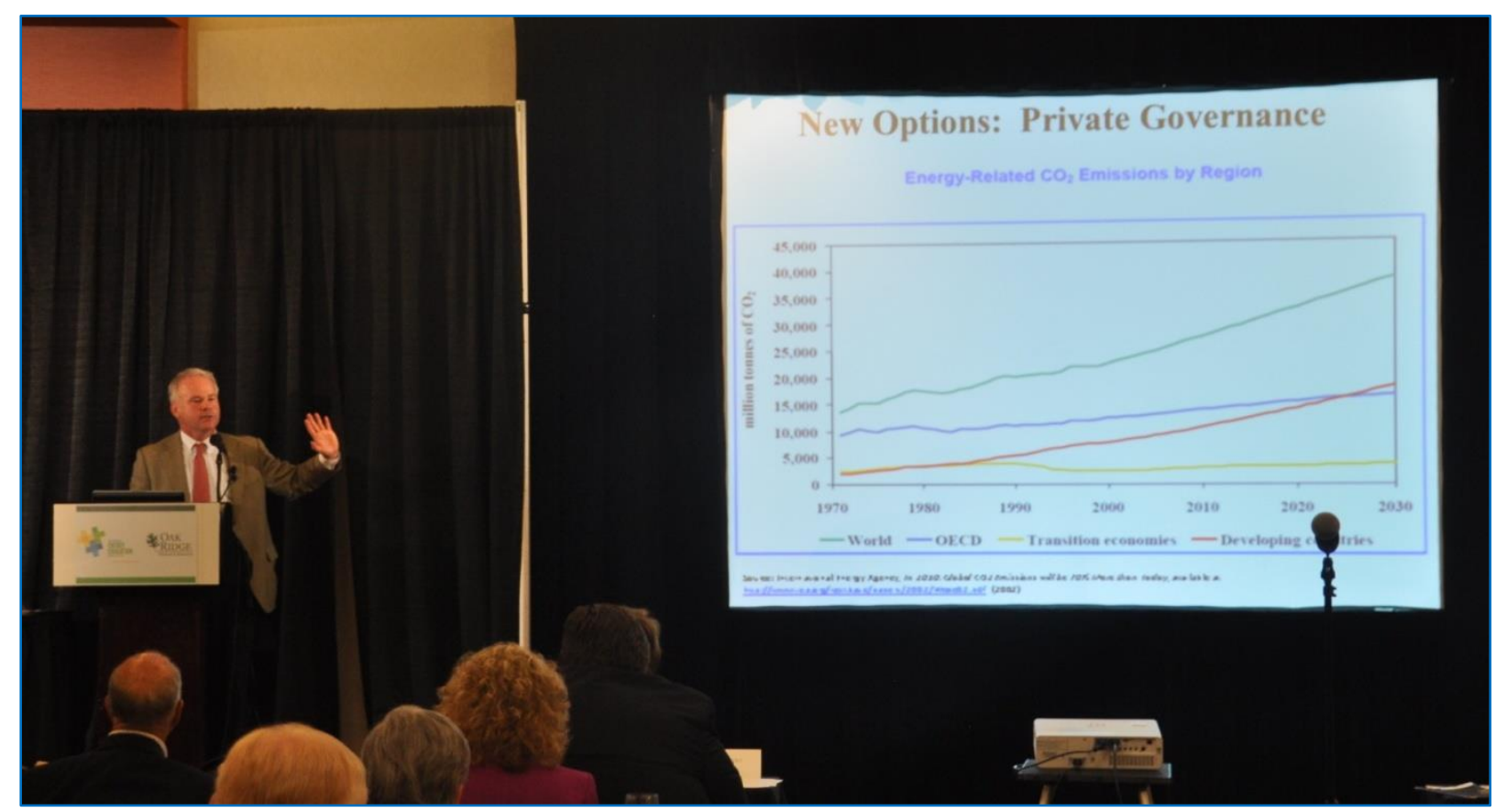

Figure 5: Keynote speaker Mike Vandenbergh discusses keys to understanding drivers of human behavior 


\subsection{Doubling Energy Productivity in the Southeast - The Key to Becoming a 21st Century Economic Powerhouse}

The Alliance to Save Energy (ASE) is composed of 16 members of Congress and 35 businesses, nongovernmental organizations (NGO), and academic leaders who consider energy efficiency their first and best resource. Their mission is "to promote energy efficiency worldwide to achieve a healthier economy, a cleaner environment, and greater energy security."

Last year, the Alliance Commission adopted the goal to double energy productivity by 2030 using a 2011 baseline.

KEYNOTE SPEAKER

- Kateri Callahan, President \& Director, The Alliance to Save Energy

The Commission made 51 recommendations covering strategies to invest in energy efficiency and energy productivity improvements, to modernize government regulations and the federal approach to energy productivity, and to educate corporations and consumers on the benefits of energy efficiency. President Obama has embraced this goal and strategies as has the U.S. Conference of Mayors. At a regional level, North Carolina has adopted a number of measures which support these three basic strategies of the Alliance: investment in energy efficiency R\&D, setting state fleet efficiency requirements, creating the Innovative Pete Street Program to spread awareness of energy savings, and funding public transit.

With the Southeast as the fastest growing region in the country, ASE President and Director Kateri Callahan explained how the Alliance set up the Southeast Energy Efficiency Alliance (SEEA) to focus on efforts in that area. SEEA offers local, state, and regional support through collaborations, case studies, leverage earned media opportunities, and grassroots advocacy to help the Southeast build on the progress it has already made.

\subsection{The Market Opportunity for Energy Improvements}

In this keynote, Lee Ann Head of the Shelton Group provided a summary overview of a recent survey conducted by the Shelton Group that assesses the general awareness and motivation of businesses in Tennessee for energy efficiency efforts. The types of energy projects that have been done or are under consideration were also examined. This assessment was then used to determine which areas had the greatest opportunity for savings; the KEYNOTE SPEAKER criteria companies were looking at when considering energy efficiency upgrades, and how companies reacted to the Shelton Group's program.

Two hundred phone surveys of businesses in thirteen different industry sectors were conducted in May 2013. Healthcare, private education, retail, business services, and wholesale distribution had the highest 
number of respondents. Companies whose decision-making occurs locally comprised $89 \%$ of survey respondents, with national and international level decision-making taking $10 \%$ and $1 \%$, respectively. Most companies surveyed, $52 \%$, had fewer than 50 employees.

The priority given to energy efficiency in facility management correlated with the number of facilities and the age of the facilities -- $83 \%$ of multi-facility organizations considered energy conservation important versus $73 \%$ of single facility groups. Companies with facilities under five years old were more likely to discount the importance of managing energy consumption. Results were broken down further by industry sector.

According to the results, businesses prefer projects with a payback period of two-years or less. As a result, the top two type of projects performed and considered overall by respondents were lighting upgrades and HVAC improvements. Spending less on energy and saving money were the top reasons cited by groups for efficiency upgrades while a lack of funding and low priority status were cited as the top barriers to efficiency improvements. Finally, the Shelton Group states that the simplest way to encourage the adoption of efficiency measures is through projects which parallel industry priorities. 


\section{LOCAL TOURS}

\subsection{Downtown Knoxville}

Led by Teresa Nichols of the ORNL Sustainable Campus Initiative, the tour of Downtown Knoxville included the LEEDcertified Convention and Transit Centers as well as the Knoxville Coliseum solar-assisted EV charging stations.

The Convention Center has implemented a number of sustainability measures for which it has been awarded its LEED Silver certification. It is also the first Convention Center in Tennessee to earn a LEED certification. Measures include daylight harvesting and window tinting, two photovoltaic arrays installed on the Center roof, and a vegetative roof. Indoor conditions are monitored and controlled by motion sensitive light switches and new high-efficiency boilers. The Convention Center also planted trees indoors to improve air quality, changed their landscaping to reduce water consumption, and implemented single-stream recycling. Through the singlestream recycling effort, the Convention Center diverts 13-15 tons of recycling each year. (10)

The Transit Center located downtown also recently earned LEED Silver certification and includes many of the same efficiency measures as the Convention Center. A solar array is installed on the bus station's upper level, and the Transit Center features a vegetative green roof and day-lighting controls. An energy-efficient building envelope was used for the bus station hub, including super-insulated windows, as well as materials with high recycled content and low-emitting materials. (11)

At the Coliseum, tour participants visited six Blink Level 2 charging stations installed in the parking deck. The EV charging spots are powered in part by an adjacent $14.4 \mathrm{~kW}$ solar array. This installation is part of the nationwide EV Project, which was supported by DOE grant funding. $(12,13,14)$
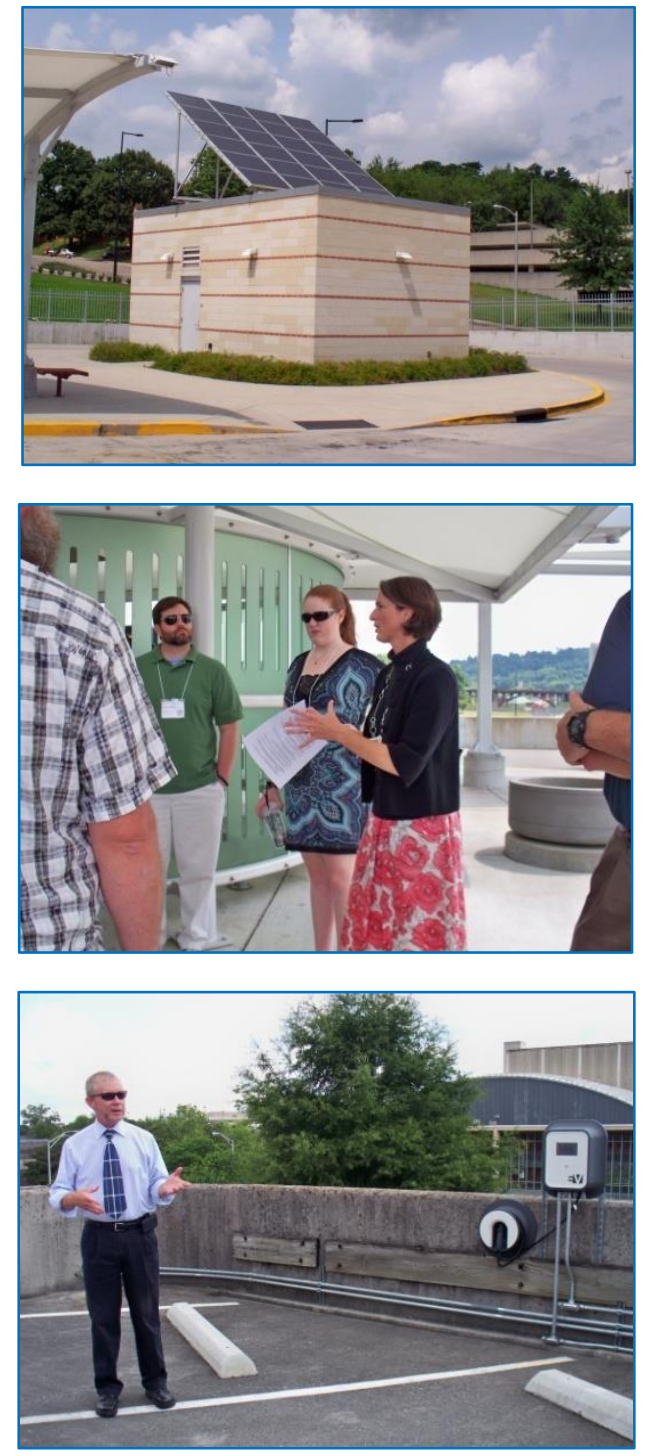

Figure 6: The Downtown Knoxville tour includes viewings of the LEED ${ }^{\circledR}$ Silver Certified Convention Center, the LEED $^{\circledR}$ Silver Certified Transit Center, and the Knoxville Coliseum's solar-assisted EV charging stations. 


\subsection{University of Tennessee Campus}

Melissa Lapsa, from ORNL's Sustainable Campus Initiative, led the University of Tennessee campus tour, which included stops at the Living Light House, an e-bike station, and solar-assisted EV charging stations.

The Living Light House was the University of Tennessee's entry into DOE's 2011 Solar Decathlon. It now functions as a laboratory to measure the energy efficiency of devices and to assess new technologies. Features used in constructing the House include a dynamic double façade system of alternating translucent and transparent panes and horizontal blinds. An energy recovery ventilator uses air from this double façade system to provide passively warmed or cooled air to the building. Additionally, cylindrical modules in a 10.9-kW PV array capture sunlight across a $360^{\circ}$ surface, and a programmable blind system provides year-round lighting and shading while sensors automatically control indoor electric lighting. (15)

The electric bicycle sharing program on the University of Tennessee campus is a pilot program and is the nation's first fully automated electric bicycle sharing system. A total of 14 ebikes and six conventional bicycles are being used at two e-bike sharing stations on the campus. Each station consists of an integrated bike rack and battery-charging kiosk. The goals of this pilot are to 1) determine whether e-bicycles are operationally and economically feasible and 2) gauge the general public response to the technology. Sponsored by the UT Student Sustainability Initiative, Southeastern Transportation Center, and the Tennessee Department of Transportation, the e-bikes are aimed at reducing environmental degradation, overreliance on insecure energy, and public obesity. (16)
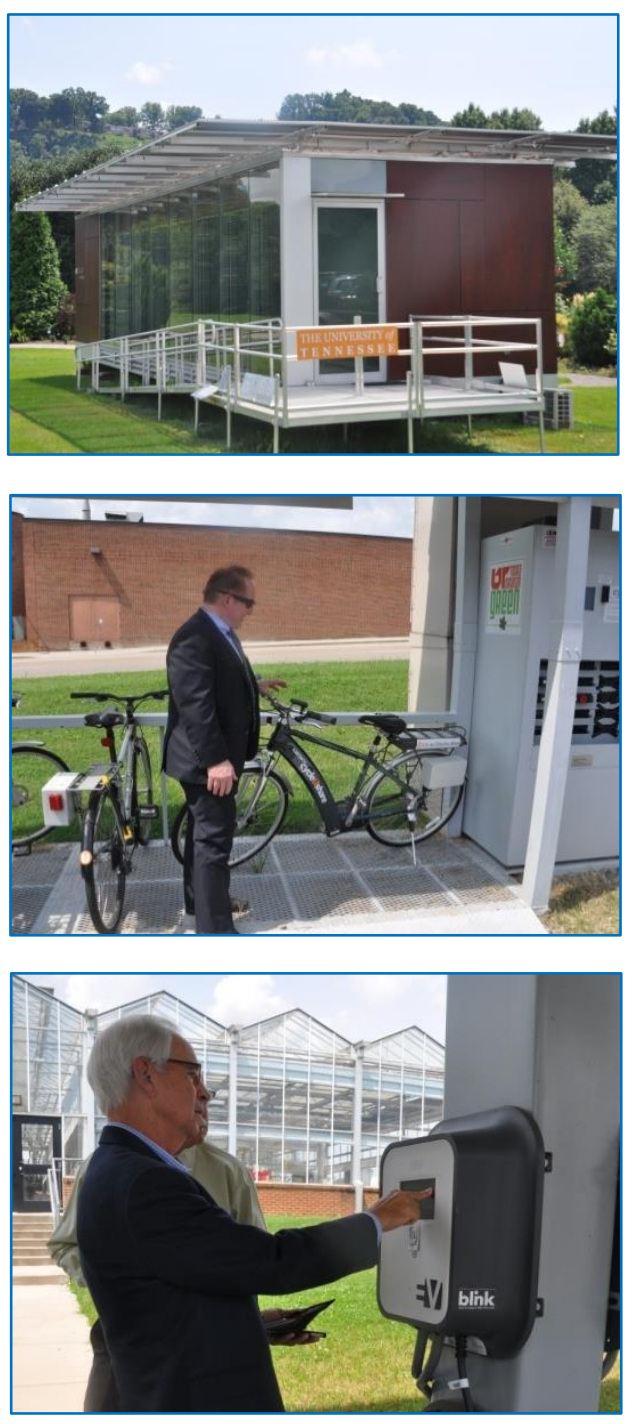

Figure 7: The University of Tennessee tour consisted of Living Light House, the Agriculture Campus' E-Bike Program, and the Agriculture Campus' solar-assisted EV charging stations.

The University of Tennessee - Knoxville has six solar-assisted EV charging stations located on the Agriculture Campus, which served as the final stop on the tour. These stations, plus six more on the university campus, were installed under the DOE EV Project. Users must have a Blink Network membership card or a Blink guest access code to utilize the stations. Like the Coliseum, the charging spots use Blink Level 2 chargers using standard SAE J1772 connectors. The solar panels supporting the station are installed on an overhead canopy, providing drivers with shade in addition to renewable charging. $(17,18)$ 


\section{REFERENCES}

**Most speaker presentations may be found on the TEEI website:

http://tnenergy.org/resourcecategories/orn/s-3rd-annual-southeast-sustainability-summit-august-21-

$\underline{22 /}$

1. "Region 4: About Us." U.S. Environmental Protection Agency, December 2008.

2. Burns, Erin, Beth Reed Fritts and Madelein Weil. "Knoxville's Energy Inventory: Government and Community Analysis and Strategic Plans." Policy \& Communications Department City of Knoxville, May 2009.

3. "Department Overview." Tennessee Department of Environment \& Conservation, Accessed September 2013.

4. "PACE Financing." Database of State Incentives for Renewables \& Efficiency Department of Energy Office of Energy Efficiency\& Renewable Energy, Accessed October 24, 2013.

5. Lapsa, Melissa. "Southeast Regional Initiative." Oak Ridge National Laboratory, August 22, 2013.

6. "Qualified Energy Conservation Bonds ("QECBs") \& New Clean Renewable Energy Bonds ("New CREBs")" Office of Energy Efficiency \& Renewable Energy U.S. Department of Energy, May 27, 2010.

7. Healthier Hospitals Initiative, Accessed September 2013.

8. "Nissan Green Program." Nissan, Accessed September 2013.

9. CityCraft Ventures, Accessed September 2013.

10. "Green on the Inside \& Out." Knoxville Convention Center, Accessed September 2013.

11. "Knoxville Transit Center." McCarty Holsaple McCarty, Accessed September 2013.

12. "Knoxville Civic Auditorium \& Coliseum - Knoxville, TN EV Charging Station." CarStations, Accessed September 2013.

13. "Solar Assisted Charging Station for Electric Vehicles Project." Tennessee Valley Authority, June 2010.

14. "24 EV Charging Stations Available in the City." News Release City of Knoxville, Tennessee, September 27, 2012. 
15. "The University of Tennessee Living Light: UT Solar Decathlon House." Solar Decathlon, U.S. Department of Energy, July 29, 2012.

16. "UT Launches Nation's First Fully Automated E-Bike Sharing System." Tennessee Today, The University of Tennessee Knoxville, September 6, 2011.

17. "University of Tennessee - Knoxville Music - Knoxville, TN EV Charging Station" CarStations, Accessed September 2013.

18. "UT 'Plugs In' to Electric Vehicle Technology." Tennessee Today, The University of Tennessee Knoxville, October 29, 2012. 


\section{APPENDICES}

Appendix A: 3rd Annual Southeast Sustainability Summit Program 


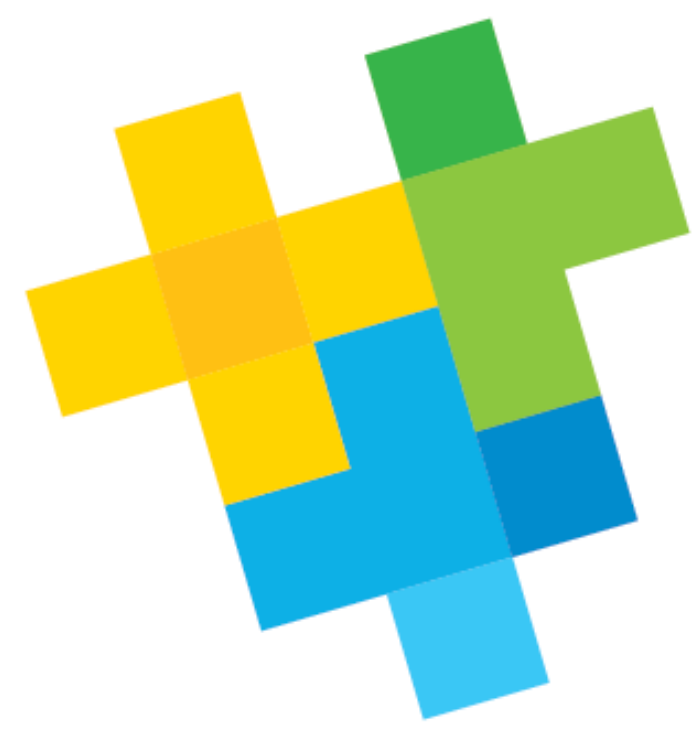

TENNESSEE

ENERGY

EDUCATION

Power, Positive. Progress.

Presented by Oak Ridge National Laboratory in collaboration with the Tennessee Energy Education Initiative \& the City of Knoxville

August 21-22, 2013 Holiday Inn World's Fair Park, Knoxville, TN 
The road to energy improvements starts here. 


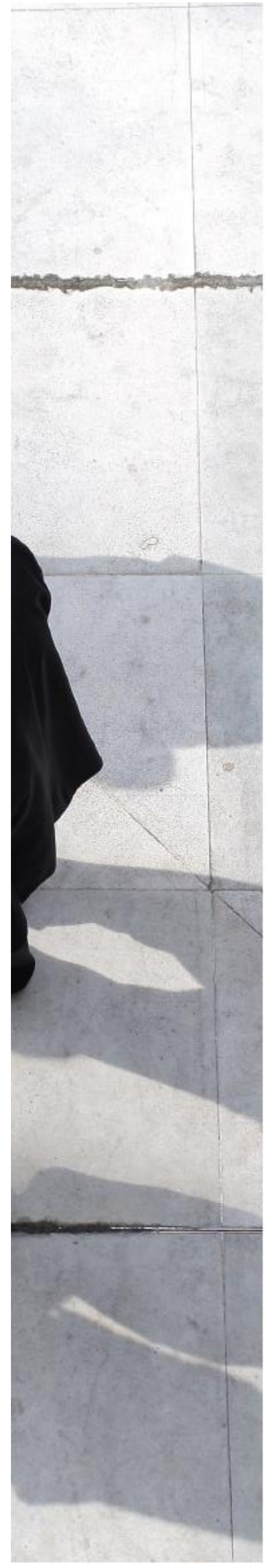

The Tennessee Energy Education Initiative provides training, tools, and local events to help organizations in Tennessee take control of their energy usage. By connecting you with the right resources, expertise, peer experience, and potential funding options, the Tennessee Energy Education Initiative provides a roadmap to successfully navigate the changing energy landscape.

This initiative is brought to you by the Tennessee Department of Environment and Conservation Office of Energy Programs, Pathway Lending, and other statewide energy resource providers. Funding is provided by the U.S. Department of Energy through the American Reinvestment and Recovery Act.

\section{About This Event}

We have convened regional and national experts to share insights, case studies, and practical knowledge needed to implement energy efficiency, renewable energy, and energy management projects, as well as other sustainable practices. Over the next two days, you will learn about technologies that can be used to save energy in ways you never thought possible and energy solutions that can be put to work today.

Oak Ridge National Laboratory has organized and hosted two Sustainability Summits since 2011 with the goal of sharing best practices among all its participants. The summits are part of ORNL's Sustainable Campus Initiative, created to integrate energy and resource efficiency and cutting-edge technologies with operational and business processes. Twenty-six unique projects, ranging from foundational methods to transformational technologies, are underway at ORNL. ORNL strives to be a leader in sustainability by embracing sustainable practices and using its vast scientific and technical expertise to benefit individuals, communities, commercial and industrial facilities, and the nation at large. 


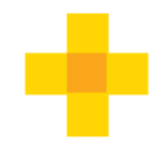

\section{Featured Speakers}

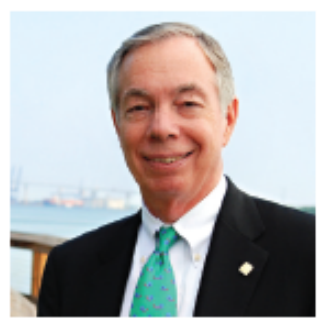

John L. Knott, Jr.

\section{Founder \& CEO, CityCraft" Ventures}

With over 40 years of experience, John L. Knott, Jr. is recognized as a thought leader and keynote speaker on sustainable development, the green economy, and restoration of cities. He created CityCraft ${ }^{\mathrm{SM}}$, a development/ planning process that restores cities' economic, environmental, and social health. His award-winning projects include Dewees Island and the Noisette Community in South Carolina.

Knott is the first executive director for the Health Product Declaration Collaborative, a standards-setter in the building industry. He has served in numerous other leadership roles, including several with the Urban Land Institute, and he has advised the White House, the Department of Homeland Security, and major corporations and municipalities around the globe on energy security and sustainability.

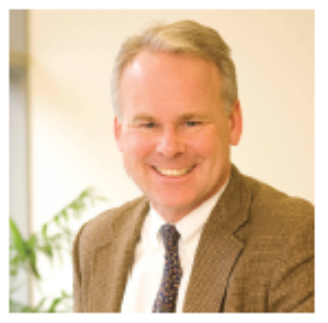

\section{Mike Vandenbergh}

Professor of Law, Vanderbilt University;

Co-Director, Energy, Environment, \& Land Use Program; Director, Climate Change Research Network

Mike Vandenbergh, a leading scholar in environmental and energy law, researches the relationships between legal and social regulation of individual and corporate behavior, including the influence of social norms on firm behavior and the effects of private contracting on public governance. As director of Vanderbilt's Climate Change Research Network, he works with interdisciplinary teams that focus on carbon emission reductions. He also serves as co-director of the law school's Energy, Environment, and Land Use Program.

A recipient of the Hall-Hartman Teaching Award, he teaches courses in environmental law, energy, and property. Previously, Vandenbergh was a partner at a national law firm. He served as Chief of Staff of the Environmental Protection Agency from 1993-1995.

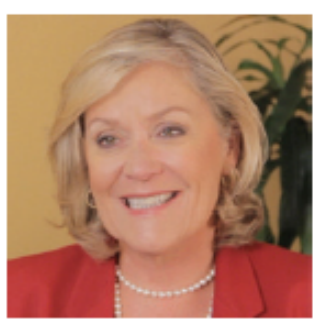

\section{Kateri Callahan}

President \& Director, The Alliance to Save Energy

Kateri Callahan has served since 2004 as president, director, and principal spokesperson of the Alliance to Save Energy. She has testified on numerous occasions before Senate and House committees and spoken before the United Nations, the U.S. Energy Association, and many other organizations. Under her leadership, the Alliance has had success in reversing the erosion in federal funding for Department of Energy efficiency programs.

Callahan serves on many boards and advisory councils, including as co-chair of The Keystone Center Energy Board. Prior to joining the Alliance, Callahan served 11 years as executive director of the nonprofit Electric Drive Transportation Association. In 2009, she was an inaugural inductee to the new Energy Efficiency Hall of Fame.

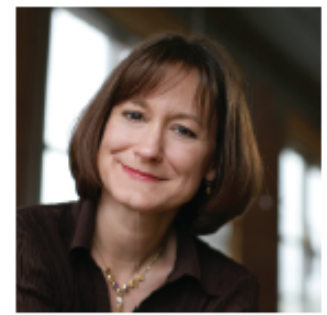

Lee Ann Head

VP Research \& Insight, Shelton Group

Lee Ann Head started Shelton Group's research department 12 years ago. Now, as vice president of research and insight, she oversees all custom and proprietary research, including the agency's national Pulse studies. She directs a staff that designs quantitative and qualitative studies, oversees secondary analyses, and is central in the process of applying research findings to the agency's strategic and creative work. She regularly presents research and insights to clients and industry groups around the country.

Before joining Shelton Group, Head's 11 years in banking included serving as senior vice president of marketing for BankFirst. She has deepened her extensive experience in marketing research with training from the Burke Institute and the American Marketing Association. 


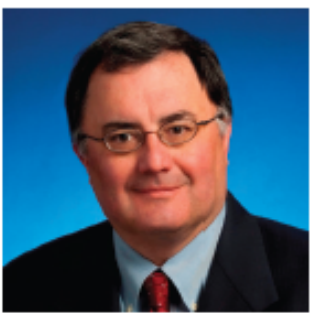

Bob Martineau

Commissioner, Tennessee Department of Environment \& Conservation

Since 2011, Bob Martineau has served as commissioner of the Tennessee Department of Environment \& Conservation, the chief environment and natural resources regulatory agency in Tennessee. He spent more than 25 years as an environmental law attorney, including seven years at the Office of General Counsel for the U.S. EPA and a decade as a partner at Waller Lansden, PLLC in Nashville.

In private practice, Commissioner Martineau helped business and local government clients anticipate issues proactively, navigate permit processes, solve problems, and establish effective environmental management programs. He has long been recognized as one of Tennessee's foremost experts and authors on environmental law, particularly as it relates to the Clean Air Act.

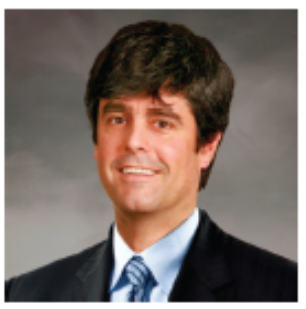

Thomas E. Mason

\section{Director, Oak Ridge National Laboratory}

Thom Mason is director of Oak Ridge National Laboratory (ORNL), where he has served in several capacities since joining the lab in 1998. His research has focused on the application of neutron scattering techniques to novel magnetic materials and superconductors. As director of the U.S. Department of Energy's largest science and technology lab, he is interested in advancing materials, neutron, nuclear, and computational science to drive innovation and technical solutions relevant to energy and global security.

Before joining ORNL, Mason was a faculty member in the Department of Physics at the University of Toronto. From 1992 to 1993, he was a Senior Scientist at Risø National Laboratory. Mason is a Fellow of the AAAS, APS, and NSSA.

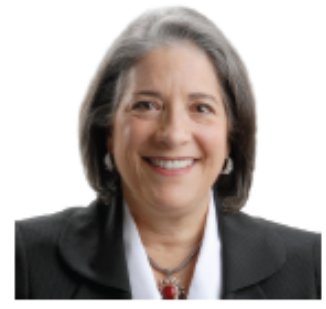

Madeline Rogero

Mayor, City of Knoxville

The first woman to be elected mayor of Knoxville, Madeline Rogero is dedicated to promoting a vibrant local economy, strong neighborhoods, a high quality of life, a thriving downtown, and a greener city. During the past 32 years, Mayor Rogero has served Knoxville as a community development director, county commissioner, nonprofit executive, urban and regional planner, community volunteer, and neighborhood champion.

Before joining the City of Knoxville, Mayor Rogero was a community and economic development planner at Tennessee Valley Authority and the East Tennessee Community Design Center. She has served as a consultant for various organizations including America's Promise - The Alliance for Youth, The University of Tennessee Community Partnership Center, and Dolly Parton's Dollywood Foundation.

\section{Molly R. Cripps}

Director, Tennessee Department of Environment \& Conservation's Office of Energy Programs

Molly Cripps serves as Director of the Tennessee Department of Environment \& Conservation's Office of Energy Programs (TDEC OEP), overseeing the U.S. DOE-funded State Energy Program, Energy Efficiency Conservation Block Grant Program, and State Government Energy Assurance Capabilities Grant. Cripps also oversees OEP's Energy Education Initiative, which is being delivered in conjunction with Pathway Lending and other statewide energy resource providers. The Initiative provides in-depth training and educational tools to support the implementation of energy efficiency, renewable energy, and energy management projects.

Cripps has served on the Energy Efficient Schools Council and the Tennessee State Advisory Board for the Electric Vehicle Project, and currently assists the Tennessee Electric Vehicle Advisory Council. Prior to joining the State, she practiced law for over 11 years, eight of which were spent representing local governments.

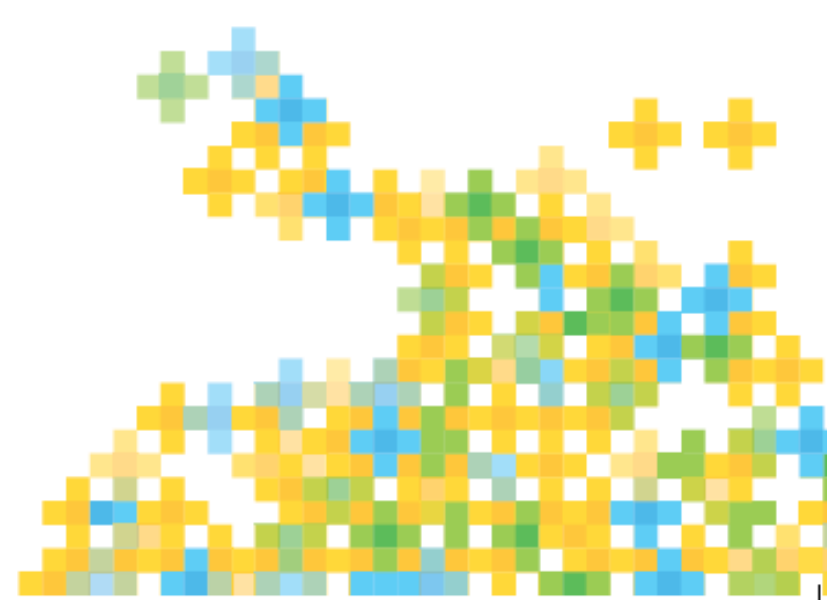




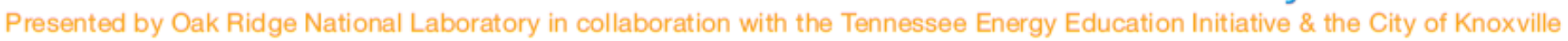
August 21-22, 2013 \#oliday Inn World's Fair Park, Knoxville, TN

\begin{tabular}{|c|c|c|}
\hline \multicolumn{3}{|c|}{ AUGUST 21, 2013} \\
\hline $8: 30$ & \multicolumn{2}{|l|}{ Registration \& Networking Breakfast } \\
\hline $9: 30$ & \multicolumn{2}{|c|}{$\begin{array}{l}\text { Opening \& Welcome } \\
\text { - The Honorable Madeline Rogero, Mayor, City of Knoxville } \\
\text { - Thom Mason, Laboratory Director, Oak Ridge National Laboratory } \\
\text { - Molly Cripps, Director, Tennessee Department of Environment \& Conservation Office of Energy Programs }\end{array}$} \\
\hline $10: 30$ & \multicolumn{2}{|l|}{ Break } \\
\hline $10: 45$ & $\begin{array}{l}\text { TRACK A: QUALIFIED ENERGY CONSERVATION BONDS } \\
\text { (QECBS) PART } 1 \text { - OVERVIEW OF TENNESSEE PROGRAM \& } \\
\text { BEST PRACTICES } \\
\text { - Katie Southworth \& Pete Westerholm, Tennessee Department of } \\
\text { Environment \& Conservation Office of Energy Programs }\end{array}$ & $\begin{array}{l}\text { TRACK B: ENERGY MANAGEMENT CASE STUDIES - A LOOK } \\
\text { AT FOUR UNIQUE INDUSTRY SECTORS } \\
\text { - Healthcare: Christopher Bodkin, Data Coordinator, } \\
\text { Healthy Hospitals Initiative } \\
\text { - Manufacturing: Richard Russell, Senior Plant Manager, } \\
\text { Nissan North America Inc. } \\
\text { - Hospitality: Ryan Cazana, Holiday Inn World's Fair Park } \\
\text { - Public Sector: Alice Dasek, Policy Advisor, U.S. Department of } \\
\text { Energy Better Buildings Challenge }\end{array}$ \\
\hline 11:30 & \multicolumn{2}{|l|}{ Break } \\
\hline $11: 45$ & \multicolumn{2}{|c|}{$\begin{array}{l}\text { Lunch with Keynote Address: A Better Way - Restoring the Long-Term Economic, Social, \& Environmental Health of Our Cities } \\
\text { - John L Knott, Jr., Founder \& CEO, CityCraft Ventures }\end{array}$} \\
\hline $1: 00$ & \multicolumn{2}{|l|}{ Break } \\
\hline 1:15 & $\begin{array}{l}\text { TRACK A: QUALIFIED ENERGY CONSERVATION BONDS } \\
\text { PART } 2 \text { - BOND FINANCING \& ELIGIBLE QECB PROJECTS } \\
\text { - Public Finance: George Masterson, Member, Bass, Berry, \& Sims } \\
\text { - National View of QECBs: Elizabeth Bellis, Energy Programs } \\
\text { Consortium } \\
\text { - Successful Projects: Glenn Barnes, UNC School of Government } \\
\text { Environmental Finance Center }\end{array}$ & $\begin{array}{l}\text { TRACK B: LIGHTING UPGRADES - THE GATEWAY TO } \\
\text { ENERGY EFFICIENCY } \\
\text { - Eric Haugaard, Director of Product Development, Cree Lighting } \\
\text { - Andre Gist, President, Manufacturing Industrial Group } \\
\text { - Jason Bourgoyne, Director of Event Services \& Operations, } \\
\text { Knoxville Convention Center }\end{array}$ \\
\hline 2:00 & \multicolumn{2}{|l|}{ Break } \\
\hline $2: 15$ & $\begin{array}{l}\text { TRACK A: DRIVING TOWARD SUSTAINABLE } \\
\text { TRANSPORTATION } \\
\text { - CNG Options for Fleets and Updates on Local Incentives: } \\
\text { Elliott Barnett, Project Identification \& Management, Strata-G } \\
\text { - Sustainable Transportation: Scott Curran, Research \& } \\
\text { Development Staff Member, Oak Ridge National Laboratory } \\
\text { - DOE Clean Cities Projects: Kristy Keel-Blackmon, Project } \\
\text { Facilitator, East Tennessee Clean Fuels Coalition }\end{array}$ & $\begin{array}{l}\text { TRACK B: STRATEGIES FOR EFFICIENT WATER } \\
\text { HEATING \& USE } \\
\text { - Knox County Jail: Casey May, Federal Business Development } \\
\text { Director, FLS Energy } \\
\text { - Solar Hot Water: Richard Kelso, Technical Advisor, CaraSol } \\
\text { - Water Heating Technology: Bill Hosken, National Sales Director, } \\
\text { A. O. Smith } \\
\text { - Energy-Efficient Water Heating Technologies: Roderick Jackson, } \\
\text { Research \& Development Staff Member, Oak Ridge National } \\
\text { Laboratory }\end{array}$ \\
\hline $3: 00$ & \multicolumn{2}{|l|}{ Break } \\
\hline $3: 15$ & \multicolumn{2}{|c|}{$\begin{array}{l}\text { Energy Checkup- Interactive Survey } \\
\text { - Rick Marsh, Director, Industrial Energy Efficiency Network } \\
\text { Road to Funding: ROI Analysis \& the Navigation of Funding Options } \\
\text { - Low-Interest Energy Loans: Clint Gwin, President, Pathway Lending } \\
\text { - Property Assessment Clean Energy (PACE) Financing: Ben Taube, President, BLT Sustainable Energy } \\
\text { - Energy Savings Performance Contracts: Julia Kelley, Group Leader, Oak Ridge National Laboratory }\end{array}$} \\
\hline $4: 15$ & \multicolumn{2}{|l|}{ Adjoum } \\
\hline $4: 30$ & \multicolumn{2}{|l|}{ Networking to Build Partnerships/Reception } \\
\hline
\end{tabular}




\begin{tabular}{|c|c|c|}
\hline $7: 30$ & \multicolumn{2}{|l|}{ Registration \& Networking Breakfast } \\
\hline $8: 00$ & \multicolumn{2}{|c|}{$\begin{array}{l}\text { Comments and Introduction of Keynote Speaker } \\
\text { - Bob Martineau, Commissioner, Tennessee Department of Environment \& Conservation } \\
\text { Keynote Address: Behavior Change - From Individuals to Institutions } \\
\text { - Mike Vandenbergh, Professor of Law, Vanderbilt University; Co-Director, Energy, Environment, \& Land Use Program; Director, } \\
\text { Climate Change Research Network }\end{array}$} \\
\hline $9: 00$ & \multicolumn{2}{|l|}{$\begin{array}{l}\text { Southeast Sustainability Group (SSG): Agents of Change } \\
\text { - Melissa Lapsa, Group Leader, Oak Ridge National Laboratory } \\
\text { - Other SSG Members }\end{array}$} \\
\hline $9: 30$ & \multicolumn{2}{|c|}{$\begin{array}{l}\text { The Department of Energy's Role in Sustainability } \\
\text {. Jennifer MacDonald, Director, U.S. Department of Energy Sustainability Performance Office }\end{array}$} \\
\hline $9: 45$ & \multicolumn{2}{|l|}{ Break } \\
\hline $10: 00$ & $\begin{array}{l}\text { TRACK A: CHANGING BEHAVIORS IN THE WORKPLACE - } \\
\text { EMPLOYEE ENGAGEMENT } \\
\text { - Jeff Rehm, Corporate Sustainability Manager, Grainger } \\
\text { - Melissa Lapsa, Group Leader, Oak Ridge National Labor atory } \\
\text { - Robin Heriges, Tennessee Green Star Partnership Overview, } \\
\text { Tennessee Department of Environment \& Conservation Office } \\
\text { of Sustainable Practices } \\
\text { - Sarah Dean, Environmental \& Regulatory Compliance Officer, } \\
\text { Mars Chocolate North America LLC; Tennessee Green Star } \\
\text { Partner ship Participant }\end{array}$ & $\begin{array}{l}\text { TRACK B: GROUND-SOURCE HEAT PUMPS - CHALLENGES } \\
\text { \& OPPORTUNITIES } \\
\text { - Alan Niles, Commercial Sales Regional Manager, WaterFurnace } \\
\text { - John Shonder, Senior Research \& Development Staff Member, } \\
\text { Oak Ridge National Laboratory } \\
\text { - Terry Townsend, President, Townsend Engineering Inc. } \\
\text { - Thomas Robinson, AlA, Director of Facilities, Planning, \& } \\
\text { Construction, Tennessee Department of Correction }\end{array}$ \\
\hline $10: 45$ & \multicolumn{2}{|l|}{ Break } \\
\hline 11:00 & $\begin{array}{l}\text { TRACK A: INSTITUTES FOR SUSTAINABLE RESEARCH } \\
\text { DEVELOPMENT \& DEPLOYMENT } \\
\text { - Howard Wertheimer, Director, Capital Planning \& Space } \\
\text { Management, Georgia Institute of Technology } \\
\text { - Martin Keller, A ssociate Laboratory Director, Energy \& } \\
\text { Environmental Sciences, Oak Ridge National Laboratory }\end{array}$ & $\begin{array}{l}\text { TRACK B: BIKE SHARE - A BETTER WAY TO TRAVEL } \\
\text { - Philip Pugliese, Bicycle Coordinator, Outdoor Chattanooga } \\
\text { - Kim Hawkins, Urban Design Architect, Metro Nashville Bicycle } \\
\text { \& Pedestrian Advisory Committee } \\
\text { - Bill Nesper, Vice President of Programs, The League of } \\
\text { American Bicyclists }\end{array}$ \\
\hline $11: 45$ & \multicolumn{2}{|l|}{ Break } \\
\hline $12: 00$ & \multicolumn{2}{|c|}{$\begin{array}{l}\text { Lunch with Keynote Presentations } \\
\text { - Doubling Energy Productivity in the Southeast - The Key to Becoming a 21st Century Economic Powerhouse } \\
\text { Kateri Callahan, President \& Director, The Alliance to Save Energy } \\
\text { - The Market Opportunity for Energy Improvements } \\
\text { Lee Ann Head, VP Research \& Insight, Shelton Group }\end{array}$} \\
\hline $1: 00$ & \multicolumn{2}{|l|}{ Adjourn \& Begin Tours } \\
\hline \multirow[t]{2}{*}{$1: 15$} & \multicolumn{2}{|c|}{ Participate in one of the following tours: } \\
\hline & $\begin{array}{l}\text { DOWNTOWN KNOXVILLE } \\
\text { - Convention Center: LEED* Certification } \\
\text { - Transit Center: LEED }{ }^{*} \text { Silver Certified, Green Roof, } \\
\text { Solar, Geothermal } \\
\text { - Knoxville Coliseum: Solar-Assisted EV Charging Stations }\end{array}$ & $\begin{array}{l}\text { UNIVERSITY OF TENNESSEE CAMPUS } \\
\text { - University of Tennessee: Living Light House } \\
\text { - Agriculture Campus: E-Bike Program } \\
\text { - Agriculture Campus: Solar-Assisted EV Charging Stations }\end{array}$ \\
\hline
\end{tabular}
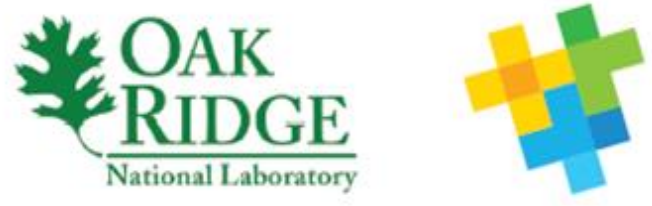

TENNESSEE

\section{ENERGY EDUCATION} INITIATIVE

Power. Positive. Progress.
For more information about the Tennessee Energy Education Initiative, please visit TnEnergy.org. 
Tennessee Energy Education Initiative Partners

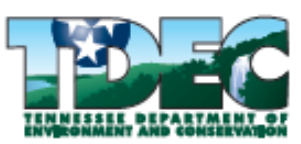

\begin{tabular}{|l|}
\hline Industria \\
Network \\
\hline
\end{tabular}

Shelton $^{\text {Gip }}$
Pathway

Lending

BLT SUSTAINABLE ENERGY

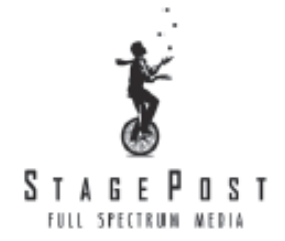

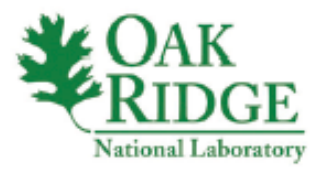
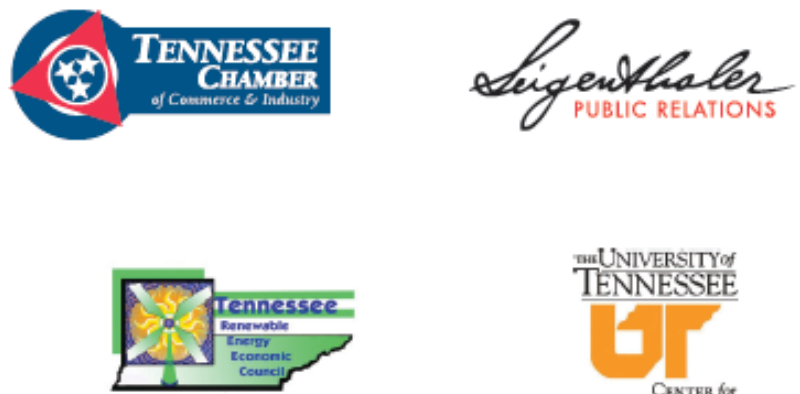

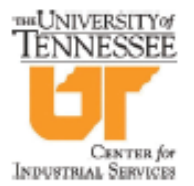

\section{Special Thanks to Our Event Sponsors}

Advanced

Tis
ADVANTAGE INNNOVATIONS
MATIONWIDE WNDOW HIM K GAAPHIC INSIALANIONS

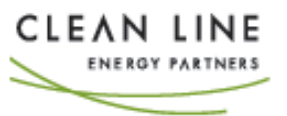

CH2MHILL.

ca

DEL MAR LIGHTING, LLC

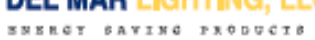

STITES $\&$ HARBISON PLC $_{\text {PLC }}$

ETcompetes!

\section{LUBRIOORP}

ARIESENERGY

\begin{tabular}{|l|l}
\hline Automated \\
\hline anergy
\end{tabular}

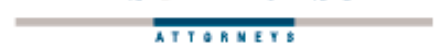

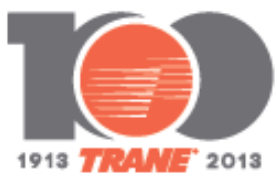

Piedmont

Natural Gas
SR̉A

Honesty and Servise*

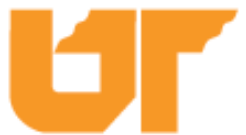




\section{Appendix B: ORNL $3^{\text {rd }}$ Annual Sustainability Summit Attendee List}

Kendra Abkowitz

Tennessee Department of Environment \&

Conservation

Harvey Abouelata

ARiES Energy, LLC

Jennifer Alldredge

Alliance to Save Energy

Ken Altman

SanSoft

Greg Armour

Pellissippi State Community College

John Atkins

TerraShares

Susan Ballentine

Univeristy of Tennessee

Robert Balzar

Tennessee Valley Authority

Glenn Barnes

UNC School of Gov. Env. Finance Ctr.

Elliott Barnett

Strata-G

Jennifer Barrie

Alliance to Save Energy

William Bauer

State of Tennessee
Angie Beach

Oak Ridge National Laboratory

Wally Beets

University of Tennessee

Elizabeth Bellis

Energy Programs Consortium

Julia Blackburn

SRA International

Jacob Blystone

Mitsubishi Electric Cooling \& Heating

Christopher Bodkin

Healthy Hospitals Iniative

Elly Boehmer

University of Tennessee

Allen Bottorff

Indian River State College

Jason E. Bourgoyne

Knoxville Convention Center

Amy Brooks

Knoxville Regional Transportation Planning

Organization

Karen Brown

Cookeville Electric Department

LK Browning

Tennessee Valley Authority 


\title{
ORNL's $3^{\text {rd }}$ Annual Sustainability Summit
}

August 21-22, 2013

Attendee List

\author{
Christopher Buhrman \\ Actio Corporate Asset Advisors \\ Amy Bunton \\ Pathway Lending \\ Chuck Burnette \\ Trane \\ Christy Cagle-Brooks \\ Tennessee Valley Authority \\ Peter Caldwell \\ Del Mar Lighting, LLC \\ Kateri Callahan \\ Alliance to Save Energy \\ Durand Carmany \\ Y-12 National Security Complex \\ Melanie Carter \\ DTR Tennessee \\ Robert Chapman \\ Tennessee Valley Authority \\ Rachael Cole \\ Interior Designer \\ Jan Compton \\ State of Tennessee \\ Kelly Conway \\ $\mathrm{CH} 2 \mathrm{M}$ Hill \\ Robert Cook \\ $\mathrm{CH} 2 \mathrm{M}$ Hill
}

Terry Cothron

B\&W Y-12

Robin Cox

City of Huntsville

Jason Crass

Oak Ridge Utility District

Bob Crawford

Piedmont Natural Gas

Molly Cripps

TN Dept of Environment \& Conservation

Clay Crownover

CFC Strategies

Scott Curran

Oak Ridge National Laboratory

Lisa Darger

University of Tennessee at Chattanooga

Alice Dasek

Department of Energy

Herb Debban

Oak Ridge National Laboratory

Joey DeLoach

Trane

Mark Donaldson

Knoxville Knox County Metropolitan Planning

Commission

Laura Duncan

TVA 


\section{ORNL's $3^{\text {rd }}$ Annual Sustainability Summit}

August 21-22, 2013

Attendee List

\author{
Stephen Dunn \\ Southeast Tennessee Development District \\ Mary English \\ UT Howard Baker Jr Center for Public Policy \\ Scott Ewing \\ Venture Incite, Inc. \\ Pat Fallon \\ City of Oak Ridge \\ Joe Fields \\ Edge Recumbent Bicycles \\ Erin Finsel \\ ARiES Energy \\ Maryl Fisher \\ Idaho National Laboratory \\ Don Fisher \\ Kendall Electric \\ Ernest Fossum \\ Idaho National Laboratory/Battelle Energy \\ Alliance \\ Charlotte Franchuk \\ Oak Ridge National Laboratory \\ Jenny Freeman \\ Strata-G \\ Sherry Furr \\ Nexant, Inc. \\ Bob Gaskill \\ Tennessee Chamber of Commerce \& Industry
}

\author{
Luke Gebhard \\ TDEC-Office of Energy Programs \\ Jason E. Gentry \\ Mid-State Construction, Inc \\ Mary Shaffer Gill \\ ARiES Energy, LLC \\ Andre Gist \\ Manufacturing Ind. Group \\ Kathy Glapa \\ State of Tennessee \\ David Graham \\ Tennessee Valley Authority \\ Jim Gray \\ Springer Publishing \\ Jimmy Green \\ Southern Alliance for Clean Energy \\ Robert Greenwell \\ CROET \\ Greg Guess \\ Kentucky Department for Energy Development \\ and Independence \\ Clint Gwin \\ Pathway Lending \\ Scott Hacker \\ Ingersoll Rand \\ Frances Hall \\ Hall Communications, Inc
}


Jason Hall

Advantage Innovations

Christopher Hardy

Clean Line Energy

Barbara Harris

Pathway Lending

Bob Harris

Black Bear Solar Institute

Eric Haugaard

Cree Lighting

Kim Hawkins

Metro Nash. Bicyc \& Ped Advisory Comm.

Lee Ann Head

Shelton Group

Nick Hegeman

Exxonmobil

Brandon Heller

Brand-One

Robin Heriges

State of Tennessee

Paul Hoffman

Pathway Lending

Richard Holland

Packaging Corporation of America

Christy Holt

NNSA Production Office Y12
Hugh Holt

Knox County Government

Bill Hosken

A.O. Smith

Patrick Huch

Shaw Industries

Bryce Hudey

UT-Battelle

Joe Hultquist

The Joseph Group

Patrick Hunt

Shelton Group

Dan Hurst

Strata-G

Mario Hurtado

Clean Line Energy

Andy Hutsell

$\mathrm{CMH}$ Manufacturing, Inc

Chris Ischay

Idaho National Laboratory

Jan Jackson

Y-12

Roderick Jackson

Oak Ridge National Laboratory

Paul Johnson

The Housing Fund 


\section{ORNL's $3^{\text {rd }}$ Annual Sustainability Summit}

August 21-22, 2013

Attendee List

Cecil Jones

Energy Power Solutions

Donna Jones

Energy Power Solutions

Rex Jones

Pathway Lending

James Kane

East TennesseeChapter USGBC

Martha Keel

University of Tennessee Extension

Kristy Keel-Blackmon

East Tennessee Clean Fuels Coalition

Martin Keller

Oak Ridge National Laboratory

Julia Kelley

Oak Ridge National Laboratory

Richard Kelso

CaraSol Energy

Penny Kemp

Shelton Group

Gannate Khowailed

SRA International

Elunga King

I Recycle Campaign

Hayley King

Balfour Beatty Investments
John Knott Jr

CityCraft Ventures, LLC

Mike Lakin

Stokes Electric Company

Lisa Lambert

Eastman Chemical Company

Chadd Landress

Lubicorp

Melissa Lapsa

Oak Ridge National Laboratory

Johan Larsen

Sustainable Future

Bonnie Latta

Tennessee Valley Authority

Audrey Lee

Ward Lenz

Advanced Energy

Donald Lesmerises

ECOGreenHotel

Karen Lively

Pellissippi State Community College

Jusbyn Lockard

Ameresco, Inc.

Steve LoJacono

Graybar 


\title{
ORNL's $3^{\text {rd }}$ Annual Sustainability Summit
}

August 21-22, 2013

Attendee List

\author{
Dolynn Loy \\ Oak Ridge National Laboratory \\ Angela Luckie \\ City of Maryville \\ Jennifer MacDonald \\ US Department of Energy \\ Chad Marcum \\ Southern Middle Tennessee Entrepreneur \\ Centers \\ Dan Marcum \\ NEST-TN \\ Larry Markel \\ SRA International \\ Rick Marsh \\ Industrial EE Network \\ Ken Martin \\ Auburn University \\ Sara Martin \\ Smart Tips \\ Bob Martineau \\ TDEC \\ Thom Mason \\ Oak Ridge National Laboratory \\ George Masterson \\ Bass, Berry \& Sims \\ Casey May \\ FLS Energy
}

David McConnell

Newport Utilities

Rory Mcllmoil

Appalachian Voices

John McMillian

Shockwave Motors

Valerie Medovich

Pathway Lending

Miles Mennell

Ameresco

Ronald Merville

Energy Source Partners

Susan Michaud

Oak Ridge National Laboratory

Kelly Miller

Advantage Innovations

Matt Moats

Pellissippi State Community College

Eric Moore

Auburn University

Mike Moran

Pacific Northwest National Laboratory

Patrick Mulligan

Patrick Environmental and Technical Services

Lori Munkeboe

State of Tennessee 


\section{ORNL's $3^{\text {rd }}$ Annual Sustainability Summit}

August 21-22, 2013

Attendee List

John Myers

Tennessee Valley Authority

Rick Nelson

Kirby Building Systems

Bill Nesper

League of American Bicyclists

Warren Nevad

University of Tennessee MTAS

Owen Nevader

Trane

Teresa Nichols

Oak Ridge National Laboratory

Alan Niles

WaterFurnace International

Steve Noe

Knoxville Utilities Board

Scott Noethen

Appalachian Renewable Resources

Sharon Nolen

Eastman Chemical Company

John Nolt

University of Tennessee

Linda Nyholm

Tech 20/20

Eric Ogle

University of Tennessee
Mark O'Gorman

Maryville College

Olugbemiga Olatidoye

Clark Atlanta University

Chris O'Reilley

SRA International

Randy Overbey

E\&S Consulting, LLC

Stefan Partin

ARiES Energy, LLC

Aprell Patterson

Y-12

Nathan Payne

Nissan North America

Mark Penland

State of Tennessee

Thomas Penson

Kendall Electric Supply

Jean Peretz

University of Tennessee

Cortney Piper

TN Advanced Energy Business Council

Jay Price

University of Tennessee

Philip Pugliese

Outdoor Chattanooga 
Jim Purcell

Automated Energy, Inc.

Kim Raia

University of Tennessee

Greg Rainey

Kellogg

Allie Rapkowicz

Piper Communications

Justin Redd

STION

Jeff Rehm

W.W. Grainger, Inc.

Lee Riedinger

University of Tennessee

Teresa Ritter

Trane

Thomas Robinson

TN Dept of Correction

Lori Rochelle

Pathway Lending

Madeline Rogero

City of Knoxville

Mark Rogers

Shaw Floors

Tom Rogers

ORNL
Bea Ross

University of Tennessee

Frank Rukavina

National Renewable Energy Laboratory

Richard Russell

Nissan North America

Thomas Ryan

Lend Lease

Lori Saal

Town of Farragut

Randy Sadler

Hummingbike Electric Bicycles

Glenn Schatz

Department of Energy

Matthew Schneider

Department of Energy

Adrienne Schwarte

Maryville College

David Seeman

University of Tennessee

Kelley Segars

Knoxville Regional Transportation Planning

Organization

Charlie Sexton

B\&W Y-12

Katy Sheesley

Hoar Construction 


\title{
ORNL's $3^{\text {rd }}$ Annual Sustainability Summit \\ August 21-22, 2013 \\ Attendee List
}

\author{
Keith Shields \\ City of Knoxville \\ John Shonder \\ Oak Ridge National Laboratory \\ Karen Sikes \\ SRA International \\ Jack Sisk \\ University of Tennessee \\ Mike Snelling \\ Nucor \\ Katie Southworth \\ TN Dept of Environment \& Conservation \\ Kenneth Srebnik \\ Nissan North America \\ Zeke Stannard \\ University of Tennessee \\ Keith Stepp \\ Knoxville Area Quadracycles \\ Don Stokes \\ Stokes Electric Company \\ Donna Stokes \\ DNV KEMA \\ Lester Stokes \\ Tennessee Valley Authority \\ Jimmy Stone \\ Oak Ridge National Laboratory
}

Jon Sturgeon

Pathway Lending

Donna Suter

Tennessee Valley Authority

Ben Taube

BLT Sustainable Energy

Warren Thomas

Oak Ridge National Laboratory

Chris Thompson

Tennessee Department of Environment \&

Conservation

Erica Thompson

Lubicorp

Rebecca Tinker

$\mathrm{CH} 2 \mathrm{M}$ Hill

Jake Tisinger

City of Knoxville Ofs of Sustainability

Terry Townsend

Townsend Engineering, Inc.

Christina Treglia

State of Tennessee

Ashley Utley

Pellissippi State Community College

Michael Vandenbergh

Vanderbilt University Law School

Dana Vaughn

Tennessee Valley Authority 


\title{
ORNL's $3^{\text {rd }}$ Annual Sustainability Summit \\ August 21-22, 2013 \\ Attendee List
}

\author{
Frank Vestal \\ Vestech Industrial Marketing \\ Lawrence Vivenzio \\ Rhoades Car \\ Jon Walden \\ University of Tennessee-CTAS \\ Joe Wallace \\ Visionary Solutions LLC \\ Adrienne Weber \\ SRA International \\ Jeff Welch \\ Knoxville Regional Transportation Planning \\ Organization \\ Howard Wertheimer \\ Georgia Tech \\ Pete Westerholm \\ TDEC \\ Chris Wetherall \\ ELB Consulting, Inc. \\ Daniel Wheeler \\ The Kellogg Company \\ Matthew Whinery \\ H\&T Enterprises
}

Jeannette Widman

Strata-G

Gisela Wieland

SanSoft

Grant Williams

University of Tennessee

Larissa Williams

MS Development Authority

Scott Williams

Venture Incite, Inc.

Daniel Wilson

Pathway Lending

Tim Wilson

Pellissippi State Community College

Cat Wilt

Center for Clean Products

Micah Wood

City of Franklin Planning Department

Jonathan Yeager

E Solutions 


\section{Appendix C: Interactive Survey Results}

1.) Identify the sector that best represents your organization.

\begin{tabular}{|r|r|r|}
\hline & \multicolumn{2}{|c|}{ Responses } \\
\hline & Percent & 10 \\
\hline Commercial & $10.75 \%$ & 9 \\
\hline Industrial & $9.68 \%$ & 10 \\
\hline Local Government & $10.75 \%$ & 9 \\
\hline Federal & $20.43 \%$ & 19 \\
\hline Government & & 36 \\
\hline Tother & $38.71 \%$ & 93 \\
\hline
\end{tabular}


2.) Does your organization have a formal written energy management plan or energy policy?

\begin{tabular}{|r|r|r|}
\hline & \multicolumn{2}{|c|}{ Responses } \\
\hline & \multicolumn{1}{|c|}{ Percent } & 46 \\
\hline Yes & $51.11 \%$ & 34 \\
\hline No & $37.78 \%$ & 10 \\
\hline Don't know & $11.11 \%$ & 90 \\
\hline Totals & $100 \%$ & \\
\hline
\end{tabular}

3.) Does your organization have an energy management team? (Multiple Choice)

\begin{tabular}{|r|r|r|}
\hline & \multicolumn{2}{|c|}{ Responses } \\
\hline & \multicolumn{1}{|c|}{ Percent } & 52 \\
\hline Yes & $58.43 \%$ & 27 \\
\hline No & $30.34 \%$ & 10 \\
\hline Don't know & $11.24 \%$ & 89 \\
\hline Totals & $100 \%$ & \\
\hline
\end{tabular}


4.) Does your organization have a procedure for employees to suggest energy savings opportunities?

\begin{tabular}{|r|r|r|}
\hline & \multicolumn{2}{|c|}{ Responses } \\
\hline & \multicolumn{1}{|c|}{ Percent } & Count \\
\hline Yes & $60.23 \%$ & 53 \\
\hline No & $32.95 \%$ & 29 \\
\hline Don't know & $6.82 \%$ & 68 \\
\hline Totals & $100 \%$ & 6 \\
\hline
\end{tabular}

5.) Has your organization had energy assessments done at its facilities in the past?

\begin{tabular}{|r|r|r|}
\hline & \multicolumn{2}{|c|}{ Responses } \\
\hline & \multicolumn{1}{|c|}{ Percent } & 62 \\
\hline Yes & $71.26 \%$ & 17 \\
\hline No & $19.54 \%$ & 87 \\
\hline Don't know & $9.2 \%$ & 87 \\
\hline Totals & $100 \%$ & \\
\hline
\end{tabular}


6.) Are departments in your organization required to track energy usage?

\begin{tabular}{|r|r|r|}
\hline & \multicolumn{2}{|c|}{ Responses } \\
\hline & \multicolumn{1}{|c|}{ Percent } & 19 \\
\hline Yes & $22.62 \%$ & 50 \\
\hline No & $59.52 \%$ & 14 \\
\hline Some, but not all & $16.67 \%$ & 1 \\
\hline Don't know & $1.19 \%$ & 84 \\
\hline Totals & $100 \%$ & \\
\hline
\end{tabular}

7.) Do you use occupancy sensors (conference rooms, copy rooms, etc.)?

\begin{tabular}{|r|r|r|}
\hline & \multicolumn{2}{|c|}{ Responses } \\
\hline & \multicolumn{1}{|c|}{ Percent } & Count \\
\hline Yes & $62.35 \%$ & 53 \\
\hline No & $35.29 \%$ & 30 \\
\hline Don't know & $2.35 \%$ & 85 \\
\hline Totals & $100 \%$ & 2 \\
\hline
\end{tabular}


8.) Has your organization completed any energy efficiency upgrade projects?

\begin{tabular}{|r|r|r|}
\hline & \multicolumn{2}{|c|}{ Responses } \\
\hline & \multicolumn{1}{|c|}{ Percent } & 68 \\
\hline Yes & $79.07 \%$ & 13 \\
\hline No & $15.12 \%$ & 5 \\
\hline Don't know & $5.81 \%$ & 86 \\
\hline Totals & $100 \%$ & \\
\hline
\end{tabular}

9.) Is your organization currently exploring energy efficiency upgrades?

\begin{tabular}{|l|l|l|}
\hline & \multicolumn{2}{|l|}{ Responses } \\
\hline & Percent & Count \\
\hline Yes & $71.43 \%$ & 60 \\
\hline No & $20.24 \%$ & 17 \\
\hline Don't know & $8.33 \%$ & 7 \\
\hline Totals & $100 \%$ & 84 \\
\hline
\end{tabular}


10.) What are the barriers for taking on energy projects at your facility?

\begin{tabular}{|c|c|c|}
\hline & \multicolumn{2}{|c|}{ Responses } \\
\hline & Percent & Count \\
\hline $\begin{array}{l}\text { Limited access to } \\
\text { financing }\end{array}$ & $48.1 \%$ & 38 \\
\hline $\begin{array}{l}\text { Not a major priority } \\
\text { for administration }\end{array}$ & $21.52 \%$ & 17 \\
\hline $\begin{array}{l}\text { No energy staff to } \\
\text { coordinate projects }\end{array}$ & $6.33 \%$ & 5 \\
\hline Other & $24.05 \%$ & 19 \\
\hline Totals & $100 \%$ & 79 \\
\hline
\end{tabular}




\section{Appendix D: Press Coverage}

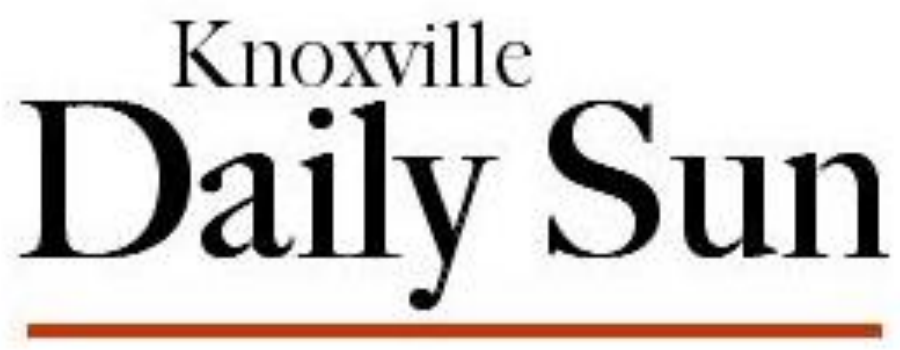

9:10 a.m. August 16, 2013

Two-day sustainability summit to be held in Knoxville

KNOXVILLE - The Tennessee Energy Education Initiative, a program of the Tennessee Department of Environment and Conservation (TDEC), is partnering with Oak Ridge National Laboratory and the City of Knoxville to host a free, two-day sustainability summit in Knoxville on August 21 and 22.

The Oak Ridge National Laboratory 3rd Annual Southeast Sustainability Summit will be held at the Holiday Inn World's Fair in Downtown Knoxville at 525 Henley Street. The first day begins with a networking breakfast, continues with two tracks of programming and concludes with a reception. The second day includes two program tracks and networking opportunities and ends with a tour of sustainability sites across the city. A full agenda and registration details can be found at TNEnergy.org/events.

"In-depth educational programming-like this summit-is critical to encouraging and enabling leaders to advance energy efficiency and sustainability," said Robert Martineau, commissioner of TDEC. "Sharing industry insights and best practices opens the door to the future of sustainable communities in Tennessee."

Presentations and discussions will focus on energy efficiency upgrades, changing behaviors in the workplace, sustainable transportation and information on energy conservation bonds. Industry experts will share case studies and provide insights and practical knowledge needed for attendees to envision and execute their own energy efficiency projects.

Keynote presenters include John Knott, Jr., founder and CEO of CityCraft Ventures; Kateri Callahan, president and director of The Alliance to Save Energy; and LeeAnn Head, vice president of research and insight at Shelton Group.

The Tennessee Energy Education Initiative was created through a public-private partnership led by the TDEC Office of Energy Programs. It provides in-depth training and educational tools to businesses, public officials and communities to support the implementation of energy efficiency, renewable energy and 
energy management projects.

Funded by the American Reinvestment and Recovery Act through the U.S. Department of Energy and TDEC Office of Energy Programs, the Tennessee Energy Education Initiative is coordinated by Pathway Lending and supported by energy-focused organizations statewide.

Information on the Tennessee Energy Education Initiative and related events is available at TNEnergy.org or through Pathway Lending at (615) 425-7171.

\section{knoxnews.com}

\section{Group to tackle barriers}

Staff Reports

Monday, September 2, 2013

A new organization has launched to bring together individuals from government, business, utilities and universities to address the most pressing sustainability issues in the Southeast.

The initiative, supported by the Department of Energy, was announced at Oak Ridge National Laboratory's Southeast Sustainability Summit in August.

Ken Srebnik, senior manager for corporate planning at Nissan, and Melissa Voss Lapsa, an ORNL senior researcher and group leader, will co-chair the effort.

"We're trying to be an agitator, to get things going and eventually these things (go) under their own steam," Thom Mason, ORNL director, said during the conference. "A lot of energy policy happens at a state and local level."

Additional founding members include the University of Tennessee, TVA, Indian River State College in Fort Pierce, Fla., and Clark Atlanta University in Georgia. With its official unveiling at the conference, the organization is now recruiting additional groups. 